\title{
DROUGHTS, CEREAL PRICES, AND PRICE STABILIZATION OPTIONS
}

\author{
Paul Dorosh, Jennifer Smart, Bart Minten, and David Stifel
}

\section{Introduction}

Increases in cereal prices can have adverse effects on poor net food buyers. Conversely, falling domestic prices of some cereals (especially maize), typically at harvest time, can be detrimental to producers who are net sellers. Price volatility is especially problematic for Ethiopia because of frequent weather shocks. The country is often hit by droughts that result in adverse effects on all farmers due to major crop failures, subsequent price instability, extremes in income streams, and severe hardship. The average rural household in Ethiopia is a net buyer when it comes to the seven most important commodities in the country (coffee, maize, beans, barley, wheat, teff, and sorghum) and hence is adversely affected by price spikes. However, price volatility more negatively affects the welfare of wealthier rural households, who are more likely to be producers, than poorer rural households (Bellemare, Barrett, and Just 2013). For surplus-producing farmers, net revenues are vulnerable to both production shocks and price volatility. Price stabilization efforts are therefore an important consideration for Ethiopian policymakers. ${ }^{1}$ This chapter evaluates options for cereal price stabilization in Ethiopia drawing on the experiences of other developing countries.

Twice in the past fifty years, crop failures contributed to widespread famines in Ethiopia (1972-1974 and 1984-1985). ${ }^{2}$ Because of their devastating effects, these famines received significant attention in the literature. In their analysis of the 1984-1985 famine, Webb and von Braun (1994) identified four major causal factors. The most important factor was drought-induced crop

1 Bellemare, Barrett, and Just (2013) find that the average household's willingness to pay to fully stabilize commodity prices at their means is about 18 percent of its income and that this may very well explain the government's frequent interest in price stabilization since, on average, households stand to benefit from it.

2 See Appendix Table 9A.1 for a chronology of major food shortages in Ethiopia over the past 50 years. 
failure. ${ }^{3}$ The other three factors reflect longer-term causes. In addition to misguided land policies and conflict, markets in Ethiopia were not well integrated. ${ }^{4}$ The latter followed from market restrictions (particularly regulation and bans on interregional movement of grain and labor), requirements for licensed private traders to make half of their purchases available to the Agricultural Marketing Corporation at fixed prices, and poor market infrastructure.

This chapter assesses how Ethiopia tried to assure food security and to achieve food price stability during the major El Niño-induced drought of 2016. A series of droughts and crop losses in 2015 and 2016 threatened the food security of an estimated 10.2 million people who were declared in need of emergency food assistance in addition to the 7.9 million already covered by the Productive Safety Net Program (PSNP) (WFP 2016a-i). Fortunately, the experiences of 2016 were very different from the earlier famines for several reasons. First, major reforms in government policies and massive public investments in agricultural extension and road infrastructure have contributed to substantial increases in cereal production (Bachewe et al. 2018; Rashid, Dorosh, and Alemu 2018). Second, the functioning of agricultural markets has significantly improved with most markets now being much more integrated (Minten et al. 2014; Hill and Fuje 2017). Third, the introduction of the well-targeted PSNP in the mid-2000s provided an effective means of providing access to food for many of Ethiopia's poorest households (Berhane et al. 2014).

The structure of the chapter is as follows. First we review the international experiences with cereal price stabilization policies and the institutional context in Ethiopia; next is an assessment of cereal price variability in the past decade in Ethiopia and a comparison of that price variability with the experiences of other East African countries. We then analyze production shortfalls

3 Per capita production of cereals fell from 154.1 kilograms per capita in 1982/1983 to 122.6 in 1984/1985 and then 91.2 and 100.4 kilograms per capita in 1985/1986 and 1986/1987 (FAO data, including Eritrea: note that FAO reports 1983/1984 production as 1983 [Seyoum Taffesse, Dorosh, and Asrat 2013]). Even taking account of increased imports (including food aid) of approximately 800,000 metric tons per year in $1985 / 1986$ and 1986/1987, per capita cereal availability overall fell from 151.5 kilograms per person in $1982 / 1983$ to 100.1 kilograms per person in 1985/1986 and 110.2 kilograms per capita in 1986/1987.

4 Government land reform policies, including abolishing private land ownership in 1975 and ceilings on private land access rights to 10 hectares per farm, were welcomed in much of central and southern Ethiopia, but subsequently government investment in agriculture was allocated mainly to state farms and producer cooperatives, instead of independent small farmers. Ongoing civil war between the Mengistu regime and both the Eritrean People's Liberation Front and the Tigray Peoples' Liberation Front resulted in loss of life and serious injuries, a reduction in labor availability for crop cultivation, and diversion of scarce public resources away from needed investments in agriculture, roads, and telecommunications. 
and policy responses in the case of the major El Niño-induced drought of 2016. Price stabilization options for the Ethiopian government are presented before our final conclusions.

\section{International Experience with Cereal Price Stabilization}

In light of the sharp rise in international cereal prices in 2007 and 2008 and a rethinking on the part of many developing countries on their policies regarding food prices, public sector food stocks, and reliance on international trade, it is helpful to review the experiences of countries that have implemented price stabilization policies. There are good reasons why governments intervene in markets to prevent excess price spikes or price declines. These include protecting the welfare of the urban poor and of rural net buyers by dampening price increases, enhancing incentives for domestic production and farmer incomes by preventing large price falls, and promoting political and social stability.

While the overall record on price stabilization is mixed, there are some success stories. Examples from South and Southeast Asia include India, Pakistan, and Indonesia, where price stability objectives have been achieved. However, price stabilization has often come at considerable cost to the public purse, along with distributional and leakage costs. Pressure from domestic farmer interest groups has led to sustained high levels of procurement (and subsequent distribution). For example, India's government procures 20 percent to 25 percent of total domestic wheat and rice production annually.

In East and Southern Africa, several countries, including Kenya, Madagascar, and Zambia, have enjoyed moderate success in raising price levels for farmers and reducing price volatility through their pricing, marketing, and trade policies. For example, the Kenyan National Cereals and Produce Board's purchases and sales of maize at administratively determined prices alongside competition from the private sector contributed to average prices for maize being 20 percent higher than they would have otherwise been between 1989 and 2004 (Jayne, Myers, and Nyoro 2008). Similarly, interventions by the Food Reserve Agency (FRA) in Zambia contributed to average maize prices being roughly 18 percent higher than they otherwise would have been between 2003 and 2008, while price volatility was more than 30 percent lower (Chapoto and Jayne 2009). In both of these cases, however, there is also evidence that these countries could have done better if their policies had been characterized by transparency and predictability. 
The importance of transparency, predictability, and ultimately more certainty is directly related to the price-stabilizing benefits of private-sector international trade. When domestic prices rise above international prices (or the effective cost of imports as measured by the import parity price), there is an incentive for private traders to import. This results in a suppression of exceedingly high price spikes. For example, following severe flooding and a rice production shortfall in Bangladesh in 1998, private-sector rice imports, made possible by earlier trade liberalization and investments in infrastructure and market development, effectively stabilized market supplies, as imported rice filled the gap, and prices, since international prices provided an upper price bound (Dorosh 2001, 2008). In relying on the international market in this manner, price stabilization can be achieved in a low-cost way without relying on government expenditures.

For international private-sector trade flows to play a price-stabilizing role, however, governments need to minimize uncertainty related to their policies and interventions. For example, uncertainty about government intentions to import or about when or whether governments will alter import duties can result in traders worrying that they will incur financial losses if they do import and the government subsequently changes its policy. The consequence of this can be a temporary underprovision of imports when there is a domestic shortfall, with resulting food shortages and price spikes above the cost of imports. On the face of it, the lack of the private-sector imports may appear to reflect market failures and a weak private sector. However, a good case can be made that the behavior of private-sector traders is a rational response to uncertainty.

This type of private-sector response to uncertain policies has been documented in such countries as Kenya, Madagascar, Malawi, and Zambia. When Kenya was hit by maize shortfalls in 2008 , private traders were reluctant to import maize because the 50 percent import duty made private importation uneconomical. The government's history of making sudden changes to the tariff (including zero-ratings), however, meant that grain traders also expected that a change was imminent. This indeed occurred in 2009 when the government eliminated the duty. The consequence of delays in government importation and in government's decision to maintain the 50 percent tariff on imports throughout 2008 was that maize prices stayed at very high levels in late 2008 despite the tumbling of world prices starting in October 2008 (Jayne and Tschirley 2009).

In Malawi, in response to what is now believed to be overstated official estimates of maize production in 2008 and 2009, the government purchased 
maize, encouraged exports, and restricted imports despite the private sector's difficulties in sourcing maize for government tenders and despite soaring prices. Suggesting that private maize traders had orchestrated the price rise, the government initially banned private maize trade and then required traders to operate within an official price band. But since market prices were well above the ceiling, traders stopped buying maize. In the end the government eventually arranged with one large trader to supply maize to the government at prices well above the official ceiling price (Jayne and Tschirley 2009).

In Madagascar, when domestic production and imports were low in 2004, the government offered tenders for imports below the tariff-inclusive import parity price for rice while leaving open the possibility that the 45 percent tariff might be waived. In this case government policy—in particular, its lack of transparency, the harassment of importers (including detaining ships with imported rice), uncertainty about tariff levels and enforcement, and an official selling price that made private-sector imports paying full tariffs unprofitable-ultimately made the situation worse than would have been the case if there had been no intervention. Total rice imports in 2004 were 100,000 metric tons below the 2003 level despite domestic market prices rising above the import parity level (Minten and Dorosh 2006; Coady, Dorosh, and Minten 2009).

Finally, Zambia has experienced unintended price-instability effects of lags between policy announcements and implementation. For example, three times in the period studied (2002, 2003, and 2008/2009) announcements of intentions to import maize resulted in market prices skyrocketing as private traders stayed out of the market for maize because they realized they could not compete against subsidized imports. Due to lags in implementing the imports, government stock levels dwindled, which contributed to panic, rationing, and rapidly rising maize prices, the opposite of the policy's intended effect. Simulations based on econometric estimates show that prices in Zambia have been more volatile with government marketing and trade policies than without them, but that this result was not due to the government's purchases/sales. Rather, it was due to uncertainty over government policy and timing of implementation (Chapoto and Jayne 2009).

The message coming out of international experiences in price-stabilization policies is that rules-based approaches to marketing and trade policies may reduce levels of uncertainty and the price instability associated with them. But, ultimately, the approach that countries take in addressing price stabilization depends on the visions that policymakers have with regard to food markets. Jayne and Tschirley (2009) classify these visions into three models of 
TABLE 9.1 Competing visions of staple food market development

\begin{tabular}{|c|c|c|}
\hline Model 1 & Model 2 & Model 3 \\
\hline $\begin{array}{l}\text { Rely on markets with limited } \\
\text { role of state }\end{array}$ & $\begin{array}{l}\text { Primary reliance on markets } \\
\text { with rules-based role of state }\end{array}$ & $\begin{array}{l}\text { Role for markets with discretionary } \\
\text { state intervention }\end{array}$ \\
\hline $\begin{array}{l}\text { Role of state limited to } \\
\text { - Public goods investment } \\
\text { - Regulatory framework } \\
\text { - Strengthening of institutions } \\
\text { and property rights } \\
\text { - Policies supportive of } \\
\text { private sector entry and } \\
\text { competition }\end{array}$ & $\begin{array}{l}\text { Role for rules-based state } \\
\text { operations } \\
\text { - Buffer stock release to } \\
\text { defend stated ceiling price } \\
\text { - Marketing board purchases } \\
\text { at stated floor price an- } \\
\text { nounced in advance } \\
\text { - Transparent rules for initiat- } \\
\text { ing state imports } \\
\text { - Public goods investments }\end{array}$ & $\begin{array}{l}\text { - Based on premise that the private } \\
\text { sector cannot ensure adequate } \\
\text { food supplies in response to } \\
\text { production shortfalls } \\
\text { - Justification for unconstrained } \\
\text { role for state intervention in mar- } \\
\text { kets to correct for market failures }\end{array}$ \\
\hline
\end{tabular}

Source: Jayne and Tschirley (2009).

how markets work and how the private and public sectors interact. These are described in Table 9.1.

In Model 1 the role of the state is confined to providing public goods to strengthen markets. This vision relies on the private sector to carry out the main direct marketing functions and is close to the "Washington Consensus" around the desirability of an expansion of market forces within domestic economies, which is now generally out of favor. In Model 2 the role of the state is expanded to include direct marketing operations based on the premise that markets do fail in certain circumstances and that direct rules-based nondiscretionary state operations are necessary to maintain good prices within reasonable bounds. The price bounds are typically defined by long-run import and export parity prices. Finally, Model 3 is a vision in which discretionary state intervention provides the state with the flexibility needed to achieve state policy objectives. The staple food market policies of most governments in East and Southern Africa are characterized by this vision in that they adopt highly unpredictable and discretionary trade policies.

While Model 3 is the most common vision underlying the approaches of governments in food markets, this discretionary approach to food price policy creates risks for the private sector and hampers the private sector from performing the functions envisioned of it in Models 1 and 2. Transitioning from Model 3 to Model 2 is likely to promote market predictability and lead to greater supplies and price stability in food markets during times of domestic production shortfalls. The challenge in moving from policies motivated by Model 3 to those consistent with Model 2, however, is convincing people of the credibility of governments' commitments to a rules-based approach given long histories of discretionary state intervention in food markets. 


\section{Approaches to Price Stabilization and Safety Nets in Ethiopia}

Although the role of the state has been substantially less than in the $1980 \mathrm{~s}$ and early 1990s (Rashid and Negassa 2012; Rashid et al. 2018), Ethiopia's price-stabilization and safety net policies in the past two decades have involved substantial discretionary state interventions (Model 3). For example, the government's price-stabilization and safety net programs typically involve importing several hundred thousand tons of grain per year. In addition, private-sector international trade, including wheat imports (Dorosh and Ahmed 2011), has been severely hampered by foreign exchange and trade restrictions (for instance, import licensing requirements). The fact that this international grain trade takes place almost exclusively through the major seaport in neighboring Djibouti means that high transport and marketing costs make cross-border trade even less attractive to private-sector traders.

Three main institutions govern and implement Ethiopia's price stabilization and safety nets: the Ethiopian Grain Trade Enterprise (EGTE), the Emergency Food Security Reserve Agency (EFSRA), and the National Disaster Risk Management Commission (NDRMC). EGTE is tasked with stabilizing grain prices by buying and selling grain in the market. EFSRA maintains relatively small food reserves (averaging about 145.1 thousand tons of cereals-139.4 thousand tons of wheat and 5.6 thousand tons of maizefrom calendar years 2009 to 2015) that are available for emergency loans of working cereal stocks to nonprofit and public relief and rehabilitation agencies, prior to the arrival of imported food aid. The NDRMC, which reports directly to the prime minister, coordinates and implements all disaster risk management and humanitarian assistance at both the international and national levels (Rashid et al. 2018).

The EGTE's grain distributions are used by the government of Ethiopia to influence the supply of wheat and flour in urban areas. Millers are entitled to buy wheat from the EGTE at prices about 30 percent lower than the price the EGTE paid for it. Flour made from subsidized wheat is then subject to a price cap. EGTE sales are concentrated in urban areas and limited to licensed enterprises. For example, in 2012 only 59 bakeries and flour mills in Addis Ababa

5 In recent years exporters have been able to retain some of their foreign exchange earnings and sell them to importers at parallel market rates. This trade has thus reduced the adverse effects of an appreciation of the real exchange rate on the real price of coffee and incentives for coffee producers (Tamru, Minten, and Swinnen 2019). 
were permitted to purchase EGTE subsidized wheat in 2012 (USDA FAS 2012). ${ }^{6}$

The Ethiopian Commodity Exchange (ECX), which is jointly owned by the private sector and the Ethiopian government, is another institution that was established (in 2008) to increase grain trade and to help stabilize markets. However, in part because of foreign exchange restrictions that limited the ability of private traders to import grain or compete with the EGTE subsidized wheat distribution system, the ECX was unable to attract substantial trade in cereals. Thus the ECX quickly changed its focus to coffee, for which all exports were required to pass through the exchange. ${ }^{7}$

\section{An Assessment of Cereal Price Variability in Ethiopia}

The above institutions have not been particularly successful in stabilizing Ethiopia's cereal prices, at least in comparison with cereal price variability in two other East African countries in recent years. In particular, we compare the variability of maize prices in Ethiopia with those in Uganda and Kenya as well as in the broader international (that is, world) market over the 20092018 period.

World wheat prices (measured in US dollars) from 2009 to 2018 were on average 28.5 percent higher than world maize prices and were also considerably more stable, with a coefficient of variation (CV) of 0.196 as compared to 0.287 for maize. Comparing across countries, Ethiopia's maize prices were more stable than both Kenya's and Uganda's in real terms, although in nominal terms they were less stable than Kenya's but more stable than Uganda's. Overall, real prices of maize and wheat in Ethiopia declined over time (growth rates of -0.31 and -0.21 percent per month), as did the real price of maize in Kenya (with a growth rate of -0.25 percent per month). Real prices of maize in Uganda were, on average, almost unchanged (a growth rate of -0.03 percent per month). (For a more detailed comparison of the variability of maize prices in Ethiopia with those in Uganda and Kenya, as well as in the broader international market from 2009 to 2018, see Appendix 9B).

6 EGTE also maintains relatively small stocks of wheat and maize, which averaged 139.4 thousand tons and 5.6 thousand tons, respectively, from 2009 to 2015 (authors' calculations from EGTE data).

7 The ECX later included sesame, another major export crop. The history of the ECX and its effects on market prices of coffee are described in Rashid et al. (2018); USDA FAS (2012); Minten et al. (2014); and Minten et al. (2019). 


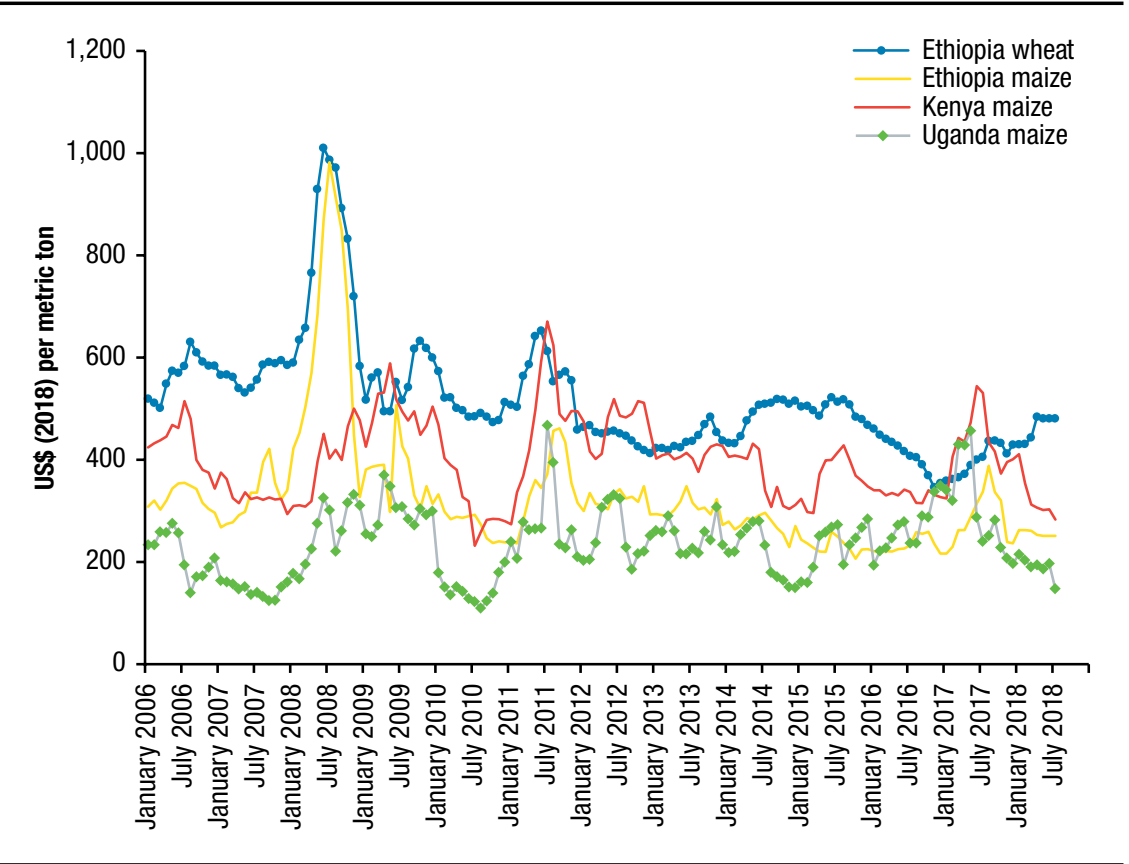

Source: Authors' calculations from Dorosh, Minten, and Stifel (2015); EGTE (2018); IMF (2018); and Ethiopia, CSA (2018) data.

Much of the variation in Ethiopian prices occurred in 2007 and 2008, a period of substantial domestic inflation. As shown in Figure 9.1, US dollar prices of maize and wheat in Ethiopia spiked in mid-2008 but have been relatively much more stable since then. A faster decline in the dollar prices of wheat relative to those of maize in Ethiopia, however, has lowered the gap between these prices over time. Unlike in Ethiopia, there has been no spike in US dollar prices of maize in Kenya and Uganda during this period, although, as indicated by the numerical measures of variance described earlier, there has been substantial variation in these prices as well.

Figure 9.2 shows the evolution of the nominal wholesale and import parity prices of wheat in Addis Ababa over the 2000-2018 period. ${ }^{8}$ In wellfunctioning integrated markets, domestic prices would not exceed the import parity prices of a product for an extended period of time if there are no

8 The import parity price is calculated as the import price of wheat at the port of Djibouti plus transport and other marketing costs to the Addis Ababa market. 
FIGURE 9.2 Ethiopia wheat prices, 2000-2018 (birr per kilogram)

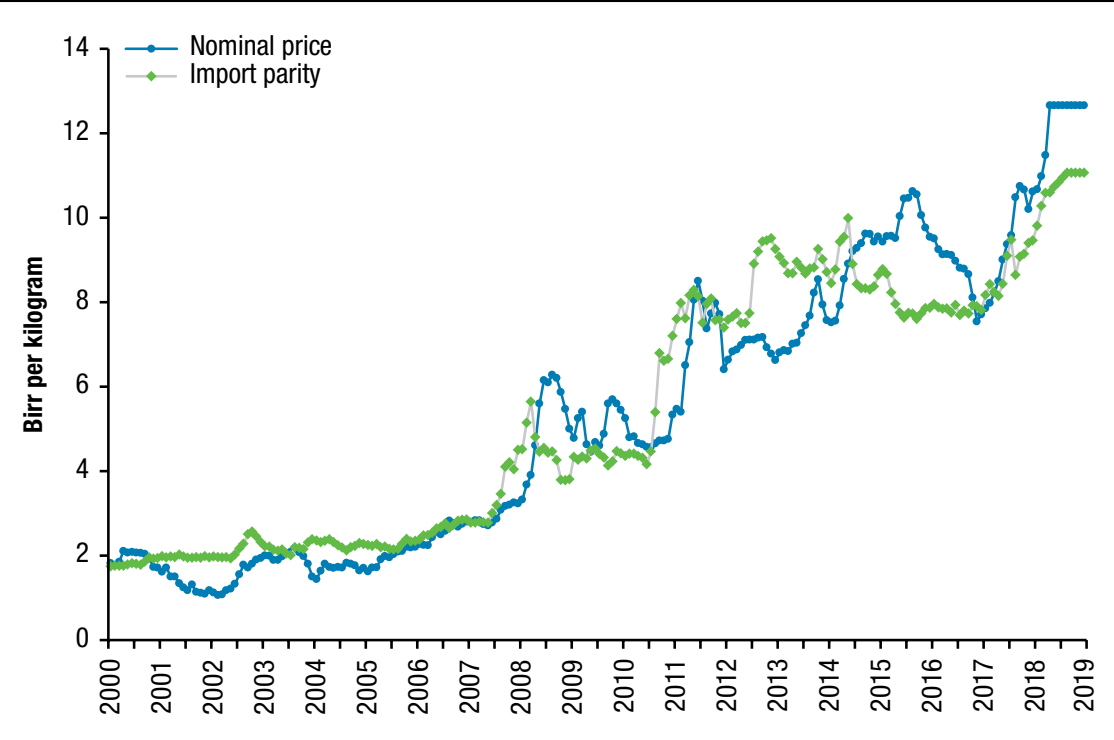

Source: Authors' calculations from Ethiopia, EPAU (2018); IMF (2018); and Ethiopia, CSA (2018) data.

Notes: Import parity in Figure 9.2 is based on international wheat prices (US Gulf, Hard Red Winter) and international shipping costs.

restrictions on trade. Nominal prices of wheat were, in fact, equal to or lower than import parity from mid-2010 to mid-2014. However, from early 2008 to mid-2010, domestic wholesale prices were significantly higher than import parity prices because of a relatively poor harvest along with foreign exchange and wheat import restrictions that limited imports (Dorosh and Ahmed 2011). Moreover, domestic wheat prices were substantially higher than import parity prices from mid-2014 through mid-2016. As discussed below, if privatesector import flows had been unhindered in this period, domestic prices could have fallen to import parity levels, thereby reducing the adverse effects of the drought that happened during that period on net wheat consumers.

Figure 9.3 presents a similar graph for maize. As in the case of wheat, domestic wholesale prices of maize were significantly above the import parity levels of maize coming from international markets through Djibouti to Addis Ababa in 2008 and 2009 and from mid-2017 to mid-2018. Nonetheless, there were no imports of maize in these periods, suggesting that foreign exchange and trade restrictions (such as import tariffs and import licensing) may have 


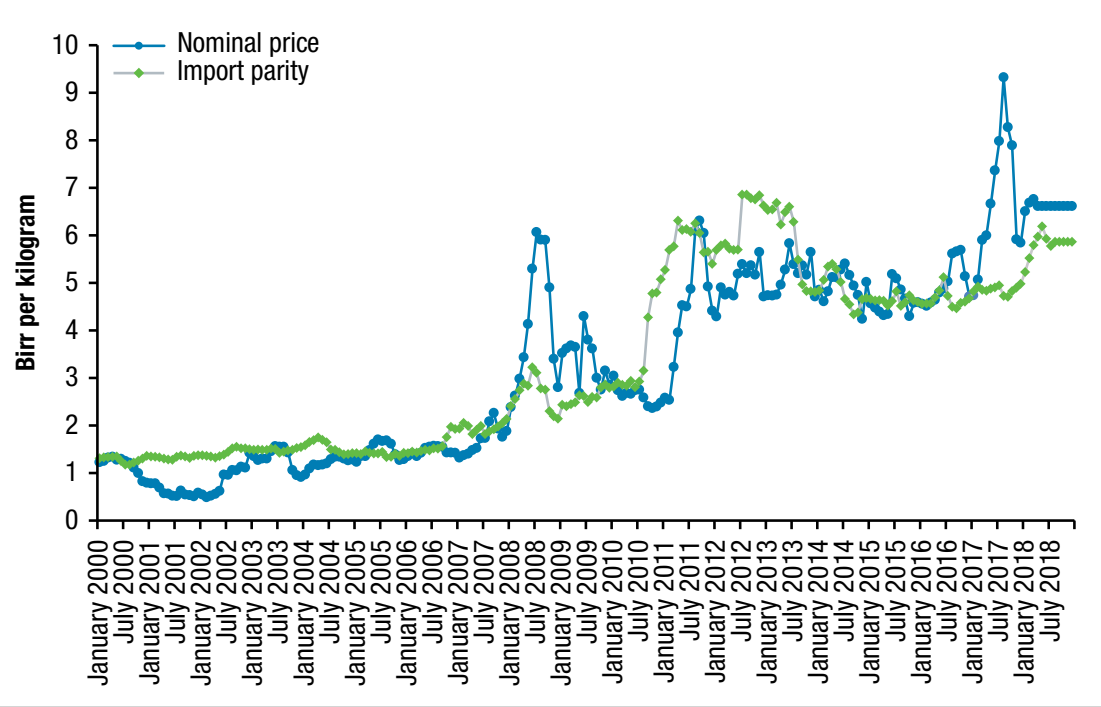

Source: Authors' calculations from Ethiopia, EPAU (2018); IMF (2018); and Ethiopia, CSA (2018) data.

prevented these import inflows. ${ }^{9}$ Note also that in early 2017 there were opportunities for exports of maize to northern Kenya, where prices were extremely high due to poor harvests. ${ }^{10}$

In summary, several key aspects of cereal price movements in Ethiopia should be noted. First, since the 2008 price spikes, wheat and maize prices have been relatively stable in Ethiopia, and overall price variability of maize is similar to that in Kenya and considerably less than in Uganda. Second, for wheat (for which there have been substantial, mostly public, imports), international dollar prices have been considerably more stable than domestic prices in Ethiopia, implying that macroeconomic instability (movements in nominal exchange rates and periods of overall price inflation) played a large role in domestic wheat price fluctuations. Third, similar price movements of wheat and maize in Ethiopia suggest that the markets for these two cereals are closely linked (Rashid and Lemma 2015) and that, as discussed next, interventions in wheat markets may help to stabilize maize prices and therefore overall cereal

9 High transaction costs because of a lack of established trade links may also have hindered flows.

10 The export parity price in western Ethiopia, measured on the basis of prices in Kenya, was somewhat higher than the import parity price of maize measured on the basis of international market prices. 
consumption. Fourth, there have been extended periods during which maize and wheat prices in Ethiopia have been above import parity prices, indicating restrictions on foreign exchange and trade.

\section{Droughts, Production Shortfalls, and Policy Response: The Case of the 2015/2016 Drought}

We present a case study of the 2015/2016 drought, its effect on cereal production and prices, and what government policy measures, regarding both imports and safety nets were put into place. We then discuss the price effects of alternative policy responses to the drought, before concluding with a discussion of effective price-stabilization options for Ethiopia. ${ }^{11}$

\section{Drought Chronology and Cereal Production}

Cereal production in Ethiopia is concentrated in the meher season with the harvest between November and January. Meher crops accounted on average for 96 percent of Ethiopia's annual total production (24.4 million metric tons) from 2013/2014 to 2015/2016 (Figure 9.4). Cereal production in the belg season, harvested between June and August, averaged only 1.04 million metric tons in this period but was highly variable, ranging from only 0.74 million metric tons in 2014/2015 to 1.48 million metric tons in 2015/2016. The poor belg harvest in 2013/2014 was due to below-average March to May shortseason rains leading to water shortages and affecting food security, especially in the eastern part of the country. According to the July 2014 report of the World Food Programme (WFP), in these areas "pastures have not adequately regenerated, water sources are poorly replenished, and crops planted during the season have suffered huge losses from water stresses" (WFP 2014a).

The belg season rains were also late and erratic in 2015, marking the start of the most severe drought Ethiopia had experienced in 50 years (AKLDP 2016). Table 9.2 and Figure 9.5 show rainfall totals in Dessie (a cereal deficit area in eastern Amhara) and Nekemte (a cereal surplus area in western Oromia) from January 2013 to June 2017. For both locations a significantly lower level of rainfall was seen in 2015. Crops were heavily damaged in Afar, Amhara, eastern and central Oromia, and pockets of Southern Nations, Nationalities, and Peoples (SNNP) regions. The drought worsened in the meher growing season (July/September), and harsh conditions spread to

11 For further details on cereal production and prices in the 2013/2014-2015/2016 period, see Dorosh et al. (2018). 
FIGURE 9.4 Ethiopia cereal harvests by season, 2013/2014-2015/2016 (million metric tons)

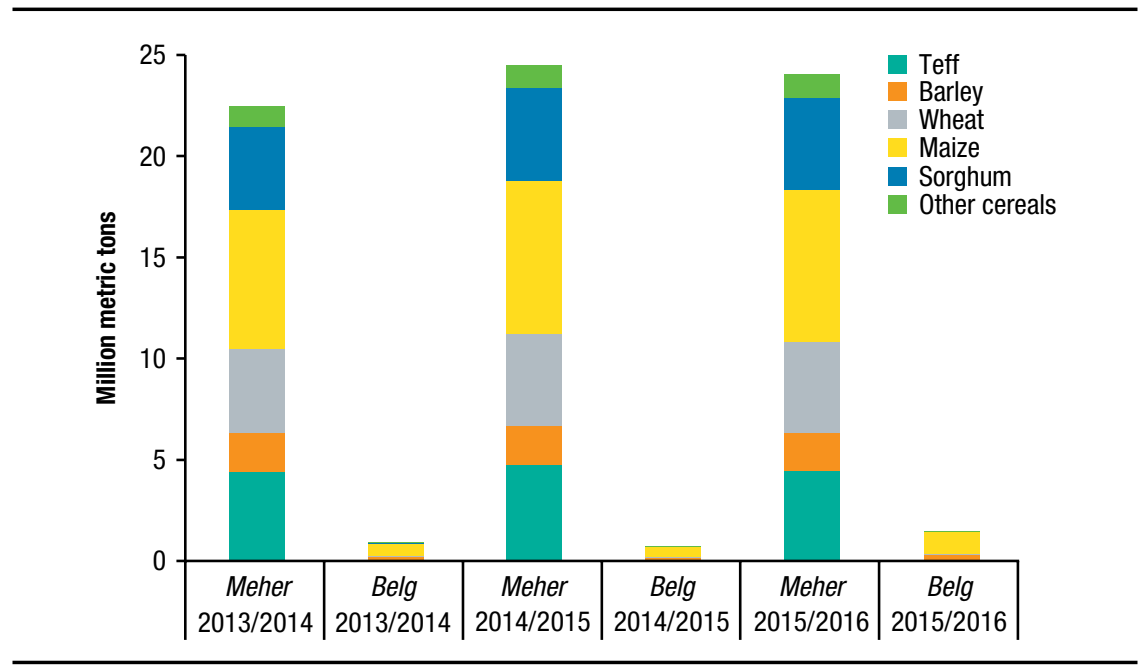

Source: Authors' calculations from Ethiopia, CSA data (2016).

Note: The meher season includes commercial farms annual production.

TABLE 9.2 Annual rainfall in Dessie and Nekemte, January 2013-June 2017 (millimeters)

\begin{tabular}{lcccc}
\hline Year & Dessie & Nekemte & $\begin{array}{c}\text { Dessie, } \\
\% \text { change to } \\
\text { year earlier }\end{array}$ & $\begin{array}{c}\text { Nekemte, } \\
\% \text { change to } \\
\text { year earlier }\end{array}$ \\
\hline 2013 & 1,021 & 1,749 & n.a. & n.a. \\
2014 & 944 & 2,008 & -7.5 & 14.9 \\
2015 & 444 & 1,276 & -56.5 & -27.0 \\
2016 & 905 & 2,003 & -11.3 & 14.6 \\
\hline
\end{tabular}

Source: National Oceanographic and Atmospheric Administration (NOAA) data (Arguez et al. 2010).

Note: n.a. $=$ not applicable.

southern and central Tigray as well as to the northern Somali region. In August the government of Ethiopia made its first calls for emergency assistance, and the WFP increased the number of people it was assisting from two million to six million by November 2016 (Table 9.3).

Ultimately, the total smallholder meher cereal harvest was only 23.1 million metric tons in 2015/2016,2.0 percent less than the 23.7 million metric tons harvested in 2014/2015. Production effects were felt far less in western Ethiopia than in the drought-prone highlands, where maize 
FIGURE 9.5 Monthly rainfall in Dessie and Nekemte, January 2013-June 2017 (millimeters)

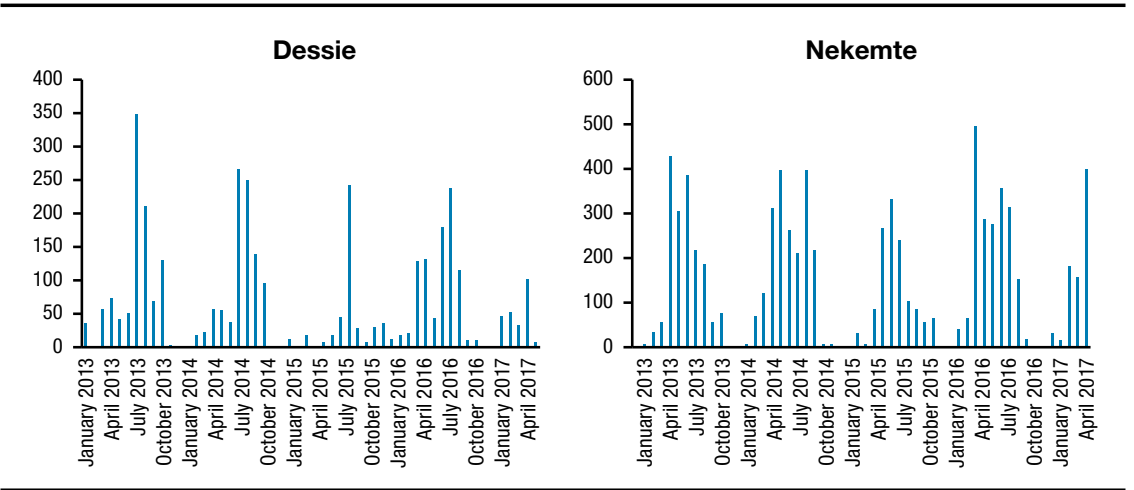

Source: National Oceanographic and Atmospheric Administration (NOAA) data (Arguez et al. 2010)

TABLE 9.3 Drought chronology for Ethiopia, 2014-2017

\begin{tabular}{|c|c|c|}
\hline Period & Summary & $\begin{array}{c}\text { Size of population } \\
\text { declared as in need } \\
\text { of emergency relief } \\
\text { (millions) }\end{array}$ \\
\hline $\begin{array}{l}\text { March-0ctober } 2014 \\
\text { (belg 2013/2014) }\end{array}$ & $\begin{array}{l}\text { Below-average belg rains lead to water stresses and } \\
\text { affect food security primarily in the east. }\end{array}$ & 3.2 \\
\hline $\begin{array}{l}\text { March-May } 2015 \\
\text { (belg 2014/2015) }\end{array}$ & Belg rains are late and erratic, causing failed harvest. & 2.9 \\
\hline August 2015 & $\begin{array}{l}\text { The government of Ethiopia makes its first calls for } \\
\text { emergency assistance. }\end{array}$ & 4.5 \\
\hline $\begin{array}{l}\text { November 2015 } \\
\text { (meher 2015/2016) }\end{array}$ & $\begin{array}{l}\text { The main meher harvest is reduced by } 50 \text { percent to } \\
90 \text { percent in the drought-affected highlands. Farmers' } \\
\text { incomes decrease up to } 60 \text { percent compared to the year } \\
\text { prior. }\end{array}$ & 8.2 \\
\hline $\begin{array}{l}\text { March-May } 2016 \\
\text { (belg 2015/2016) }\end{array}$ & $\begin{array}{l}\text { As in } 2015 \text {, late and unevenly distributed belg rains cause } \\
\text { flooding in the Somali region, and displacement, the } \\
\text { disruption of public services, and the spread of disease } \\
\text { continue. }\end{array}$ & 10.2 \\
\hline $\begin{array}{l}\text { June-September } \\
2016\end{array}$ & $\begin{array}{l}\text { Drought and food insecurity lessens in the northeast } \\
\text { after improved belg rains but worsens in the southeast } \\
\text { pastoralist areas of Somali and SNNP regions. }\end{array}$ & 9.7 \\
\hline February 2017 & $\begin{array}{l}\text { Distress migration, drought-induced school drop-outs and } \\
\text { border tensions increase in primarily Somali pastoralist } \\
\text { areas. }\end{array}$ & 5.6 \\
\hline May 2017 & $\begin{array}{l}\text { The new } 2016-2017 \text { drought continues to get worse as } \\
\text { the year progresses. }\end{array}$ & $\begin{array}{c}7.8 \\
\text { (projected) }\end{array}$ \\
\hline
\end{tabular}

Source: WFP reports (WFP 2014a, 2014b, 2015a, 2015b, 2016a, 2016b, 2016c, 2016d, 2016e, 2016f, 2016g, 2016h, 2016i, 2017a, 2017b, 2017c).

Note: SNNP = Southern Nations, Nationalities, and Peoples. 
production was worst affected. Meher maize production in 2015/2016 was down 5.8 percent in the drought-prone highlands from the year prior, compared to only 1.2 percent for Ethiopia as a whole. Meher season teff and barley production shortfalls in the highlands were also larger: -13.1 percent and -10.1 percent in the highlands, respectively, compared to -5.9 percent and -4.9 percent for the country as a whole.

Six regions of the country were reported to be severely affected by the drought, and 10.2 million people were reported in need of food assistance by April 2016 (on top of the people that were already covered by the Productive Safety Net Program [PSNP]). The drought significantly weakened coping capacities, further extensive floods caused displacement, diseases broke out, basic public services were disrupted, and more than 1 million livestock died with 1.7 million more at risk. Combined, this amounted to approximately 3 percent of Ethiopia's total livestock population (see Table 9.4 for a chronology of the livestock losses during the drought). At the time of the 2016 drought (April 2016), WFP reported that "the poorest 20 percent of the population can meet, on average, only 15 percent of their food needs through their own means, while 76 percent eat, on average, only one meal per day. Eighty percent of the affected population are consuming fewer calories than the daily minimum recommended by WHO" (WFP 2016b). These findings are broadly consistent with national household survey data presented in Chapter 10 that show (1) cereals in general are consumed by nearly all households; (2) cereals are the most important calorie source in the country, making up just more than 60 percent of total calories for the average household; and (3) 25.6 percent of Ethiopians are food energy deficient even outside of the specific effects of a given drought period, with poor diet quality only exacerbated by the losses in livestock and associated animal-sourced foods that contribute to more diverse and nutritious diets, discussed in Chapter 8 (Chapter 10 elaborates more on these dietary quality trends).

April and May 2016 were marked by late and unevenly distributed spring rains. Nonetheless, belg maize production in 2016 was twice that of 2015: 1.06 million metric tons versus 0.49 million metric tons. In the drought-prone highlands, production increased from 0.04 million metric tons to 0.21 million metric tons between the two years. Overall, total cereal production from the meher and belg seasons combined decreased by 2.0 percent between $2014 / 2015$ and 2015/2016. In the drought-prone highlands, total cereal production considering both seasons combined fell very little.

By July 2016 the regions with the worst food consumption levels shifted to Somali and SNNP. May floods during the main wet season $(g u)$ in the 
TABLE 9.4 Livestock losses chronology for Ethiopia, 2014-2017

\begin{tabular}{ll}
\hline Period & Summary \\
\hline April and May 2014 & $\begin{array}{l}\text { There are 4,000 livestock deaths in Afar region due to flooding, 2,000 livestock } \\
\text { deaths in Oromia region due to drought. }\end{array}$ \\
May 2015 & $\begin{array}{l}\text { Abnormal livestock deaths are on the rise in Somali region. } \\
\text { Over one million livestock die over the course of the poor 2015/2016 meher season, } \\
\text { March 2016 }\end{array}$ \\
largely in Afar and Somali regions, with 1.7 million more at risk. \\
March-May 2016 & $\begin{array}{l}\text { Belg rains are good, even in pastoral areas, greatly ameliorating dire conditions. } \\
\text { November 2016 }\end{array}$ \\
January 2017 & $\begin{array}{l}\text { There are 6,000 livestock deaths reported in Oromia just from October to November. } \\
\text { Livestock death counts are in the tens of thousands again by January. In parts of }\end{array}$ \\
May 2017 & $\begin{array}{l}\text { Somali, 35 percent to 55 percent of total livestock holdings die. } \\
\text { require survival and supplementary feed as the 2017 drought gets worse. }\end{array}$ \\
\hline
\end{tabular}

Source: FEWSNET reports including June 2014, May 2015, Outlook June 2016-2017, and FAO reports from March 2016, November 2016, January 2017, and May 2017.

Note: In 2014 there was estimated to be a total of 54 million cattle, 26 million sheep, and 24 million goats in the country (Leta and Mesele 2014). This would make the one million deaths at the end of the 2015-2016 drought almost 1 percent of the total livestock population, with closer to 2 percent at risk of death by March 2016.

Somali region again left homes, fields, and more livestock destroyed. This was followed by a prolonged hagaa dry season. Hagaa is the lesser of the two dry seasons of the agricultural year, typically lasting from July to September, and precedes the deyr season of short rains. The difficult hagaa season in 2016 quickly deteriorated food security and led to distress migration as pastoralists trekked further afield with their animals looking for water and grazing. By late 2016 the prolonged drought and food insecurity lessened in the northeast after improved belg rains, and good rains enabled a successful meher harvest throughout most of Ethiopia, even while hundreds of thousands of livestock were still left in critical condition primarily in Somali pastoralist areas.

\section{Market Prices and Government Policy Measures: Imports and Safety Nets}

The main policy instrument used to counter the adverse effects of the 2015/2016 drought and crop shortfalls was to increase cereal imports for humanitarian aid and expanded food distribution through PSNP. ${ }^{12}$ Ethiopia imported 2.46 million metric tons of wheat from July 2015 through

12 Ethiopia's PSNP transfers (1) reduce poverty (the food gap) by half a month; (2) reduce vulnerability (the expected food gap) given a drought has occurred, from 4.14 months to 1.8 months ( 57 percent decline); and (3) increase resilience by reducing the food gap by a further 1.75 months after a drought and reducing the time to recover, from four years to two (Knippenberg and Hoddinott 2017). 
FIGURE 9.6 Ethiopia's wheat imports by import channel, 2014/2015-2016/2017 (thousand metric tons)

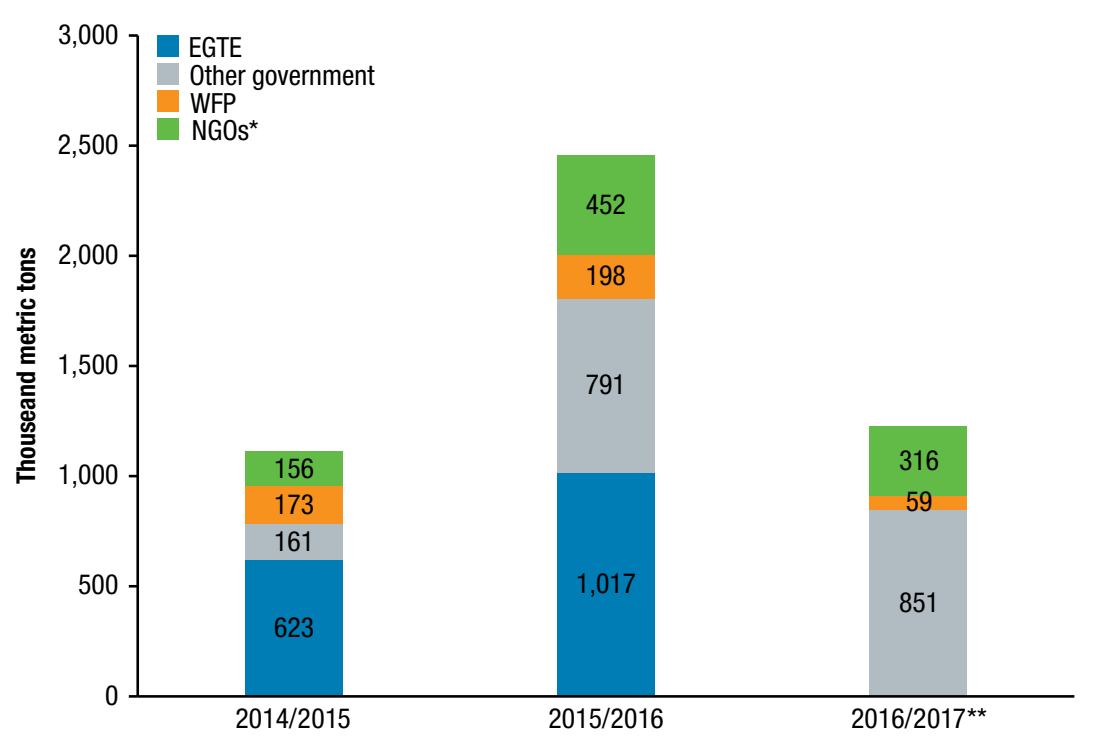

Source: EGTE and Ethiopia customs data (ERCA).

Note: Each set of years represents the months from July to June. EGTE = Ethiopian Grain Trade Enterprise; WFP = World Food Programme; NGO = nongovernmental organization. *Includes private trade equal to 25,000 metric tons in 2014/2015 and 2,000 metric tons in 2015/2016. *^Data from July 2016 through March 2017.

June 2016, 1.35 million metric tons more than in the same period in 2014 to 2015 (Figure 9.6). The EGTE imported more than 40 percent of this wheat (1.02 million metric tons) but only distributed 556 thousand metric tons through its own sales channels. The other 1.11 million metric tons were imported by the World Food Programme, other NGOs, and other government channels (Figure 9.6).

Most of these imports (including some of those imported by the EGTE) were distributed through PSNP in return for labor for households with able-bodied members, or as direct support free of charge elsewise (Wiseman, Van Domelen, and Coll-Black 2010; Coll-Black et al. 2013), which benefited 8 million people in 2015 (although more than 10 million additional people were reported to be in need of food aid due to the drought). Data from nationally representative surveys from before (2014) and after (2016) the drought indicate that the share of households residing in drought-exposed areas were 7.5 percentage points more likely, or more than twice as likely, to have received humanitarian assistance in 2016 compared to the year prior (2015). The 
FIGURE 9.7 Nominal wholesale Addis Ababa cereal prices and national wheat distribution, 2014-2017

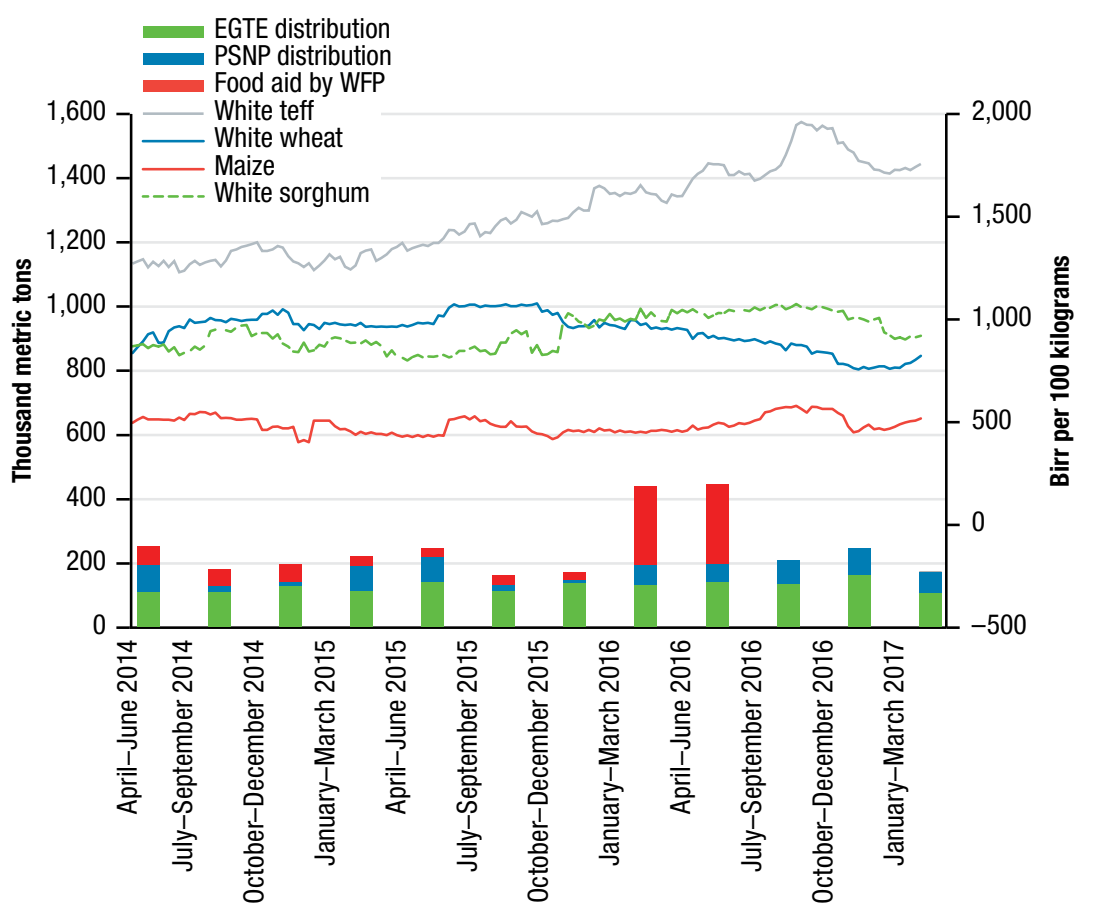

Sources: Authors' calculations from Ethiopia, CSA data (2018); EGTE (2018) data; Ethiopian Revenues and Customs Authority (ERCA) data; the IFPRI PSNPIV 2013 baseline survey (2017); FAOSTAT data for recent years on food aid shipments (WFP); USAID (2016); and Tesfanews (2016).

Note: EGTE $=$ Ethiopian Grain Trading Enterprise; PSNP = Productive Safety Net Program; WFP = World Food Programme

share of households enrolled in PSNP also increased between 2014 and 2016, increasing from 10 percent to 12 percent among the surveyed households (Hirvonen, Sohnesen, and Bundervoet 2018).

Monthly price movements during this period reflect the massive wheat import flows and overall changes in supply and demand. As wheat imports increased sharply in early 2016, the price of wheat (as recorded in the Addis Ababa retail market) fell below that of sorghum (Figure 9.7). The real price of wheat in Addis Ababa fell by 13.9 percent between 2014/2015 and 2015/2016 (Figure 9.8), while in Dessie real wheat prices fell by 13.1 percent from $2014 / 2015$ to $2015 / 2016$. By contrast, the prices of teff, maize, and sorghum in Dessie rose by 11.3 percent, 2.1 percent, and 16.1 percent, respectively, during the meher season due to the drought's adverse effects on cereal 


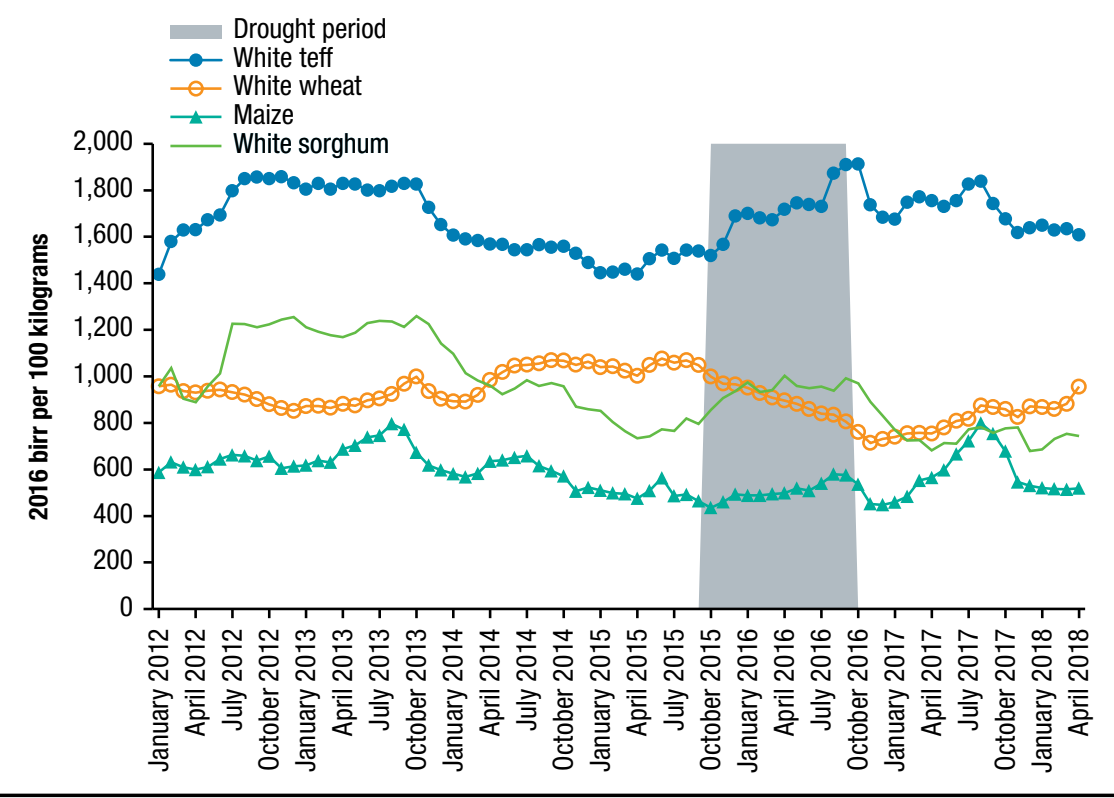

Source: Authors' calculations from Ethiopia, CSA data (2018).

production in that part of the country. The relatively small increase in real maize prices (only 2.1 percent as compared with the 11.3 percent and 16.1 percent real price increases for white teff and sorghum, respectively) reflected the relatively good maize harvest in 2015/2016 in western Ethiopia.

There is further evidence of improved functioning of markets and market integration among cereal products across regions, even in drought years (Minten et al. 2014; Hill and Fuje 2017; Bachewe, Yimer, and Minten 2017). Remarkably, there was not a widespread increase in chronic or acute child undernutrition rates in Ethiopia due to this drought, as there had been in the famine of the early 1980s, except in areas characterized by limited road networks (Hirvonen, Sohnesen, and Bundervoet 2018). This highlights the important role of market integration and public infrastructure for improved resilience to future droughts in the country. Chapter 12 discusses how urbanization, when supported by appropriate infrastructure, has the potential to boost total factor productivity and economic output through positive agglomeration effects. Mann, Warner, and Malik (2018) show that the impacts of the droughts were focused on the drought-prone highlands and therefore areas 
that typically produce less cereals, leading to lower impacts on production and prices than initially feared.

\section{The 2015/2016 Drought: Price Effects of Alternative Policies}

To estimate the effects of the drought and alternative policies on wheat consumption, imports, and market prices, we use a basic partial equilibrium framework with exogenous domestic production (Table 9.5). Supply of each cereal is calculated assuming 17 percent total losses for seed, feed, and wastage, a rate in range of the typical 15 percent to 20 percent of food availability assessed by agencies such as the World Food Programme (WFP and Ethiopia, CSA 2019; FAO and WFP 2007, 2019a, and 2019b). Household demand is modeled as a function of prices and (exogenous) income. ${ }^{13}$ In simulations where imports are exogenous, the domestic price adjusts to equate supply and demand. In Simulation 4 in which the model liberalized private-sector trade, the domestic price is set equal to the exogenous import parity price and imports are endogenous.

Simulation 1 models the effects of the historically observed production shocks to the four major cereals in Ethiopia-teff, wheat, maize, and sorghum. ${ }^{14}$ According to the official data, wheat production was almost unchanged between 2014/2015 and 2015/2016, leading to a per capita drop in production of 2.1 percent. If wheat imports would have remained the same in $2015 / 2016$ as the previous year (0.948 million metric tons in 2014/2015), then wheat supply per capita would also have fallen by 2.1 percent. At the same time, demand for wheat per capita is estimated to have risen by 4.0 percentthat is, a 5 percent increase in per capita incomes multiplied by an incomeelasticity of demand of 0.8 . Given an own-price elasticity of demand of -0.95 , domestic wheat prices would have risen by 6.2 percent.

Including production and imports of teff, maize, sorghum, and rice that are assumed to equal their actual 2015/2016 levels, the total supply of cereals falls by only 0.1 percent since maize production actually increased in this

13 The model is a simplified version of the models used for Ethiopian wheat markets (Dorosh and Ahmed 2011) and Bangladesh rice markets (Dorosh and Rashid 2013). Own-price elasticities of demand for wheat, teff, maize, and sorghum are $-0.952,-0.920,-0.735$, and 0.743 , respectively (weighted averages of urban and rural elasticities reported in Tafere et al. [2009] and Berhane et al. [2013]). Per capita incomes are assumed to have increased by 5 percent between 2014/2015 and $2015 / 2016$. We use an average income elasticity of demand of 0.8 .

14 The model does not capture potential cross-price effects of a change in price of one commodity (for example, teff) on the production or demand for another crop (for example, wheat). Note that Tafere et al. (2009) estimated cross-price elasticities very close to zero. The simulation results for "all cereals" implicitly assume perfect substitution in demand across all cereals and thus provide broad sensitivity analysis. 
TABLE 9.5 Simulated price effects of production shocks and increased imports in Ethiopia, 2015/2016 versus 2014/2015

\begin{tabular}{|c|c|c|c|c|}
\hline Simulation: & S1 & S2 & S3 & S4 \\
\hline & $\begin{array}{l}\text { Wheat } \\
\text { production } \\
\text { shock }\end{array}$ & $\begin{array}{c}\text { Wheat } \\
\text { production } \\
\text { shock with } \\
\text { higher imports }\end{array}$ & $\begin{array}{c}\text { All cereals } \\
\text { production } \\
\text { shock with } \\
\text { higher imports }\end{array}$ & $\begin{array}{c}\text { All cereals } \\
\text { production } \\
\text { shock with } \\
\text { free trade }\end{array}$ \\
\hline Wheat production ${ }^{\mathrm{a}}$ (millions of metric tons) & 4.550 & 4.550 & 3.849 & 3.849 \\
\hline Wheat production per capita (\% change) & -2.1 & -2.1 & -17.2 & -17.2 \\
\hline Wheat imports (millions of metric tons) & 0.948 & 2.483 & 2.483 & 3.103 \\
\hline Wheat supply ${ }^{\mathrm{b}}$ (millions of metric tons) & 4.724 & 6.259 & 5.677 & 6.297 \\
\hline Wheat supply per capita (\% change) & -2.1 & 29.7 & 17.7 & 30.5 \\
\hline Wheat price $(\%$ change $)$ & 6.2 & -26.0 & -13.8 & -26.8 \\
\hline All cereals supply ${ }^{c}$ (millions of metric tons) & 19.586 & 21.460 & 20.140 & 20.760 \\
\hline All cereals price (\% change) & 6.8 & -4.4 & 3.2 & -0.5 \\
\hline
\end{tabular}

Source: Model simulations.

Notes: a. Production includes commercial farms' production.

b. Supply is calculated as production minus a 17 percent adjustment for seed, feed, and wastage plus imports.

c. Supply of all cereals includes supply of wheat, maize, sorghum, teff, and rice. Supply of these nonwheat cereals is fixed at the 2015/2016 level in Simulations S1 and S2. In Simulations S3 and S4 production of teff, maize, and sorghum are each reduced by 5 percent relative to their 2015/2016 levels.

Simulation S3: The wheat production shock is set at the level at which wheat (real) price change matches historical value of -13.8 percent.

Simulation S4: Wheat imports are adjusted so that wheat (real) price change matches historical value of the percentage difference between 2014/2015 wholesale price and estimated 2015/2016 import parity price.

period. However, given a sharp 6.6 percent fall in per capita supply of teff and an 11.0 percent increase in its simulated price, the weighted average simulated real price increase of all four major cereals is 6.8 percent.

Simulation 2 models the effects of increased distribution of wheat from wheat imports (2.483 million metric tons, an increase of 1.535 million metric tons over 2014/2015). ${ }^{15}$ Given this increase in imports, net wheat supply per capita increases by 29.7 percent relative to $2014 / 2015$. The simulated wheat price falls by 26.0 percent relative to $2014 / 2015$, far greater than the historical real price decline of only 13.8 percent (Simulation 2). Again, assuming that the levels of production and imports of teff, maize, and sorghum are unchanged relative to their actual 2015/2016 levels, the average price of cereals falls 4.4 percent.

In Simulation 3 we reduce wheat production another 15.4 percent, for a total decline in per capita production of 17.2 percent, so that the simulated

15 These wheat import figures are the estimates of wheat imports actually released by EGTE for these years. See Table 4.6 in Dorosh et al. (2018) for the change in wheat supply due to imports. 
price fall (13.8 percent) matches the historical price fall. Net wheat supply per capita is then 17.7 percent greater than in 2014/2015. We also model a 5 percent reduction in production of teff, maize, and sorghum in this simulation. As a result, the average price of all cereals rises by 3.2 percent.

Finally, in Simulation 4 we simulate the counterfactual policy of allowing private-sector wheat trade at the import parity price (without tax), which was substantially below domestic prices from mid-2014 through mid-2016 (Figure 9.9). In this scenario the government of Ethiopia and NGOs procure wheat for PSNP and other programs in the wholesale market at the prevailing (import parity) price. Here, we maintain the same reduced level of wheat production as in Simulation 3 and fix the domestic price level at the estimated import parity price, which was 26.8 percent below the historical value of the wholesale domestic price of wheat in 2014/2015. ${ }^{16}$

In the case of Simulation 4 total wheat imports rise to 3.1 million metric tons and net wheat supply per capita is 30.5 percent higher than in $2014 / 2015$. Compared to Simulation 3, in which net wheat supply per capita is only 17.7 percent higher than in 2014/2015, wheat supply per capita in Simulation 4 is 10.9 percent higher (12.8 percentage points higher). In consequence, the wheat price is 15.1 percent lower, benefiting net wheat consuming households purchasing from domestic markets. As in Simulation 3, we again model a 5 percent reduction in production of teff, maize, and sorghum. Given the sharp reduction of the wheat price due to increased wheat imports, the average price of cereals actually falls by 0.5 percent, as compared to the 3.2 percent rise in Simulation 3.

Using more inelastic demand parameters, which may better reflect the behavior of consumers and markets in the short-run, produces broadly similar results (Table 9.6). Relatively high wheat production with 2.48 million metric tons of imports results in an even greater price decline ( 57.1 percent) than with the base parameters (26.0 percent) (Simulation 2a). To achieve a price reduction that matches the historical change ( -13.8 percent) requires a slightly larger reduction in production ( -28.4 percent instead of -17.2 percent) (Simulation 3a). Finally, with the alternate parameters, liberalized privatesector trade leads to a smaller increase in imports $(306,000$ versus 620,000 metric tons) (Simulation 4a).

167.68 (2016) birr per kilogram import parity in 2015/2016 as compared to 10.49 (2016) birr per kilogram average wholesale white wheat price in Addis Ababa in 2014/2015. 


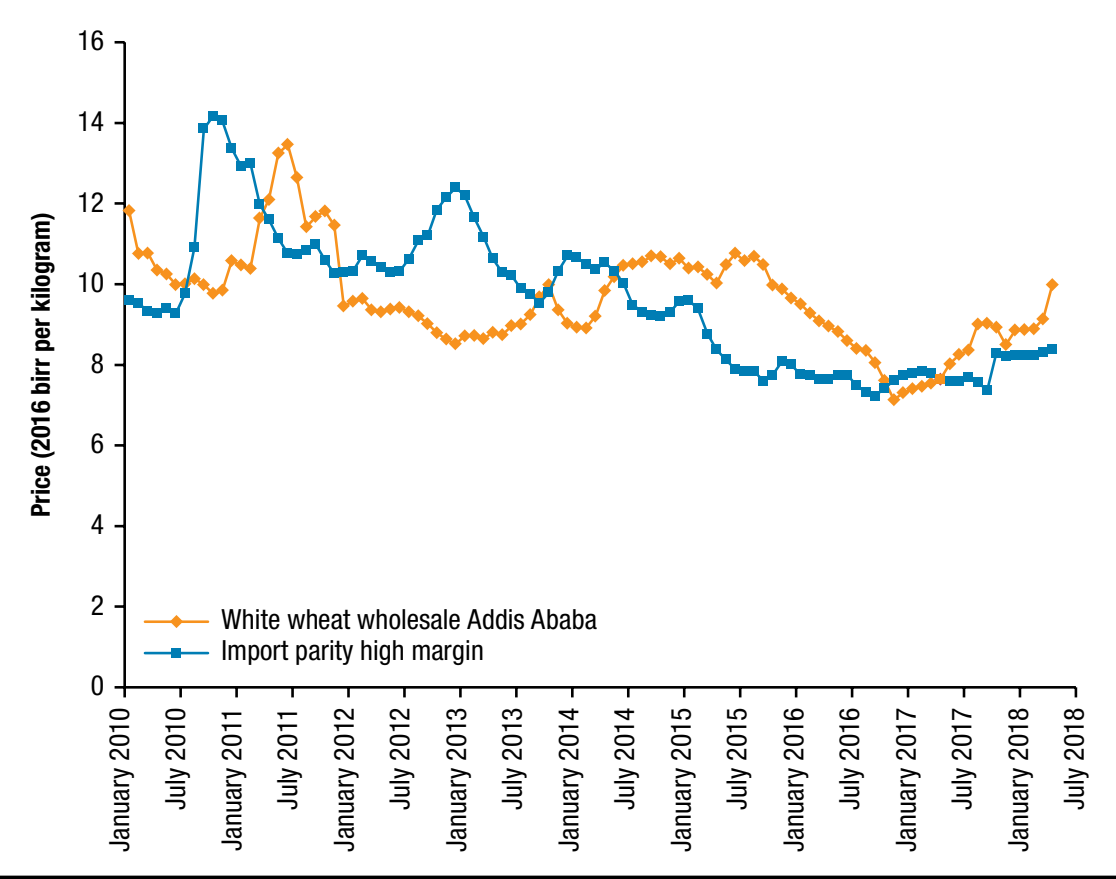

Source: Authors' calculations from Ethiopia, CSA (2018) and Ethiopia, EPAU (2018) data.

Notes: Import parity in this figure is based on wheat originating from Black Sea ports, reflecting the major source of wheat in recent years. Note that the import parity prices in Figure 9.2, which covers a longer period, are based on wheat shipped from US Gulf ports (Hard Red Winter).

Thus, liberalizing private-sector wheat imports in 2015/2016 could have provided even greater stability of supply and price. To the extent that the private sector could import wheat and bring it to wholesale markets in Addis Ababa or other major cities at a lower cost than the Ethiopian Grain Trading Enterprise (EGTE) or international agencies, the government of Ethiopia could also have reduced costs of its distribution programs. ${ }^{17}$ However, it is not always the case that the import parity price is less than a target domestic price level. When international prices are very high, stabilizing domestic prices requires either a drawdown of public stocks, food aid inflows, or subsidized sales of government commercial imports.

17 There was no explicit trade restriction in $2015 / 2016$, but private traders were not granted import licenses and foreign exchange to import wheat. 
TABLE 9.6 Simulated price effects of production shocks and increased imports in Ethiopia, inelastic parameters, 2015/2016 versus 2014/2015

\begin{tabular}{lcccc}
\hline Simulation: & S1a & S2a & S3a & S4a \\
\hline & $\begin{array}{c}\text { Wheat } \\
\text { production } \\
\text { shock }\end{array}$ & $\begin{array}{c}\text { Wheat } \\
\text { production } \\
\text { shock with } \\
\text { higher imports }\end{array}$ & $\begin{array}{c}\text { All cereals } \\
\text { production } \\
\text { shock with } \\
\text { higher imports }\end{array}$ & $\begin{array}{c}\text { All cereals } \\
\text { production } \\
\text { shock with } \\
\text { free trade }\end{array}$ \\
\hline Wheat production ${ }^{\text {a }}$ (millions of metric tons) & 4.550 & 4.550 & 3.327 & 3.327 \\
Wheat production per capita (\% change) & -2.1 & -2.1 & -28.4 & -28.4 \\
Wheat imports (millions of metric tons) & 0.948 & 2.483 & 2.483 & 2.789 \\
Wheat supply ${ }^{\mathrm{b}}$ (millions of metric tons) & 4.724 & 6.259 & 5.244 & 5.550 \\
Wheat supply per capita (\% change) & -2.1 & 29.7 & 8.7 & 15.0 \\
Wheat price (\% change) & 8.4 & -57.1 & -13.8 & -26.8 \\
All cereals supplyc (millions of metric tons) & 19.586 & 21.460 & 20.297 & 20.603 \\
All cereals price (\% change) & 9.3 & -13.6 & 0.5 & -3.3 \\
\hline
\end{tabular}

Source: Model simulations.

Notes: a. Production includes commercial farms' production.

b. Supply is calculated as production minus a 17 percent adjustment for seed, feed, and wastage, plus imports.

c. Supply of all cereals includes supply of wheat, maize, sorghum, teff, and rice. Supply of these nonwheat cereals is fixed at the 2015/2016 level in Simulations S1a and S2a. In Simulations S3a and S4a, production of teff, maize, and sorghum are each reduced by 1 percent relative to their 2015/2016 levels.

Simulation S3a: The wheat production shock is set at the level at which wheat (real) price change matches historical value of -13.8 percent.

Simulation S4a: Wheat imports are adjusted so that wheat (real) price change matches historical value of the percentage difference between 2014/2015 wholesale price and estimated 2015/2016 import parity price.

\section{Price Stabilization Options for Ethiopia}

\section{Effective Price Stabilization Policy}

The above review of the international experience with price stabilization and the case of the policy response to the 2016 cereal production shortfall and resulting drought suggests several important principles in designing an efficient price-stabilization strategy for Ethiopia. The most important elements for such a strategy are discussed below.

\section{INTERNATIONAL MARKETS}

Access to international markets to add to domestic supplies and lower prices through imports or to reduce domestic surpluses and support higher prices through exports can greatly reduce the cost of a price-stabilization policy. The alternative is to build up large stocks through domestic procurement in 
excess of distribution. ${ }^{18}$ Likely due to policymakers' high perceptions of the risk of a food crisis, the food reserve agency is mandated to hold 407 thousand metric tons of grain in its stock. However, the actual stock had not exceeded 350 thousand metric tons from 2004 to 2015, and in some quarters stocks were well below 100 thousand metric tons (Rashid et al. 2018).

International trade in wheat through food aid and government commercial imports already constitutes a major source of wheat supplies for Ethiopia. In contrast, Ethiopia's current levels of international trade in teff, sorghum, and maize are small. The lack of an international market for teff-Ethiopia is essentially the only major producer and consumer of teff globally-would make it very difficult and costly to stabilize teff prices, as it would require very large stocks. International trade in sorghum is much larger. Sudan has exported several hundred thousand metric tons in some years to countries in the Middle East. The United States is also a major exporter and a potential source of sorghum supplies for Ethiopia. Nonetheless, the international market for sorghum is rather thin. For maize there is a broad international market. Any maize exports or imports by Ethiopia would represent only a small fraction of total international trade.

Currently, high transport costs relative to the value of the grain make the import parity-export parity price band for Ethiopia very wide. As described earlier, Ethiopia’s domestic prices for maize have generally been well above export parity and mostly (but not always) below import parity. This has made both exports and imports of maize unprofitable for the private sector in most years.

\section{PROMOTING PRIVATE TRADE}

The international experience (such as in Bangladesh the late 1990s) suggests that facilitating and promoting private international trade is often the least costly, most efficient, and quickest means of enhancing and maintaining market supply and promoting price stability. The private sector can usually react much more quickly to potential domestic supply shortfalls than can public institutions (EGTE or donor food aid). Moreover, private-sector imports involve no direct costs to the government. Ethiopia's private-sector

18 To stabilize domestic prices with grain from security stocks, India holds stocks equal to about 24 percent of wheat production and 19 percent of rice production, and Pakistan holds stocks equal to about 6 percent of wheat production from 2001 to 2007 (Dorosh 2009). Ethiopia's cereal stocks averaged only 188.3 (145.1) million metric tons in 2001-2008 (2009-2015), equivalent to 1.8 (0.7) percent of cereal production (emergency food reserve agency data). 
international trade in cereals remains very small, however, mainly limited to imports of rice and high-gluten and other specialty wheat types suited for pasta or for baking purposes.

Private-sector wheat imports could substantially reduce the cost of price stabilization in Ethiopia. To a large extent, private-sector wheat imports that would otherwise have been profitable have been hindered by foreign exchange rationing, displaced by public sector imports, or made too risky because of uncertainties over government trade, exchange rate, and credit policies (Dorosh and Ahmed 2011; World Bank 2016; Dorosh and Ahmed 2009; Ferrand 2018).

\section{TRANSPARENCY AND PREDICTABILITY}

Uncertainty over government policy is a major disincentive to private-sector investment and both international and domestic trade. Yet price-stabilization regimes with frequent and abrupt policy changes are common. ${ }^{19}$ Such regimes characterize what is often the least efficient price-stabilization alternative, when compared to the promotion of international trade using rules-based price-stabilization policies (see Table 9.1). Unfortunately, a lack of transparent and predictable policy has characterized price-stabilization efforts in much of East Africa and resulted in unnecessary price instability in Kenya, Malawi, and Zambia, with important fiscal costs as well as adverse effects on the food security of poor consumers.

One option for promoting transparency and predictability of policies and for fostering trust between the private sector and government is to establish a platform for discussions of current market conditions, current and planned government policies, and ideas for promoting more efficient markets, such as investments in key infrastructure.

\section{ADMINISTRATIVE AND MARKET PRICES}

Administratively setting prices can seriously weaken the ability of markets to stabilize food prices. This was seen during Madagascar's rice price crisis of 2004/2005, when official prices were set below import parity levels, effectively ending incentives for private-sector imports. Price targets are best achieved through market mechanisms by either adding to supply or making purchases from the market to increase demand. Thus it is important to communicate

19 Examples include periodic bans of maize exports in Zambia and Malawi (Diao and Kennedy 2016; Gondwe and Baulch 2017) and Ethiopia's seizure of private coffee stocks in 2009 (Minten et al. 2014). 
that the target price (or better, a target price band) is a policy objective, but not a binding restriction on market transactions.

\section{Guidelines for Implementation of Cereal Price Stabilization}

Setting clear objectives and specific rules for interventions could contribute to successful cereal price stabilization in Ethiopia. The following elements as part of such a strategy should be considered.

\section{PRICE TARGETS AND MARKET INTERVENTIONS}

Annual target ceiling and floor prices for wheat, maize, and sorghum could be set. Current policy involves a government sales price and an implicit target (ceiling or floor) price that is not necessarily equal to the government sales price. The implicit goal of the interventions is often to reduce private market prices to the target ceiling price levels. Setting the target ceiling price for imported commodities at long-term import parity levels will ensure that the marginal cost of domestic production is equal to the long-term opportunity cost of alternative supplies from the international market, thus promoting an efficient use of resources. In years of relatively low import parity prices, keeping the target ceiling price at the higher long-run import parity price will provide incentives for private-sector imports and make public interventions unnecessary. In years of high import parity prices, subsidized sales of government imports may be required to maintain market prices at the target longrun import parity level.

The margin between floor and ceiling prices should be wide enough to give incentives for private-sector storage and trade. If the band is too narrow, the government may crowd out most private-sector trade, buying substantial amounts of grain to defend the floor price and then later selling grain to defend the ceiling price. This pattern of government interventions in cereal markets is seen in Pakistan where public procurement and subsequent sales, usually within the same crop marketing year, accounts for more than 20 percent of total wheat production, crowding out the private sector and entailing huge fiscal costs. Setting a low price with a wide margin between the floor and ceiling prices can avoid the need for any domestic procurement.

\section{MANAGEMENT OF PUBLIC STOCKS}

Public stocks are needed for an effective government price-stabilization program. About 60 percent of the grain stocks in Ethiopia are held by the Ethiopian Emergency Strategic Food Reserve Agency, while the remaining stocks are in the hands of the EGTE, in a few mills, and a small amount in private trader storage (USDA-FAS 2012). Stock levels should be kept to a 
minimum, however, to avoid excessive costs of storage, which include implicit interest, stock management, quality deterioration, and stock rotation costs. Food security reserve stocks are typically set according to the volume of likely distribution needs, allowing for a three- to four-month lag between the decision to import (if necessary) and the arrival of grain at distribution points. Ethiopia's emergency food reserve stocks have generally been small relative to domestic production and consumption and have been effectively managed (Graham, Rashid, and Malek 2012). From 2009 to 2015, Ethiopia's average public cereal stocks (145 thousand metric tons) were less than 1 percent of domestic cereal production. Incorporating price-stabilization objectives to this system would imply a need for larger stocks.

Price stabilization need not require huge stocks, however. As shown in Table 9.7, total stocks for Bangladesh averaged 2.9 percent of total wheat and rice production. Given that Bangladesh has two major rice harvests (and the risk of a production shortfall in both seasons in the same year is very small), this ratio of stocks to production may be rather small. India's stock to production ratio of 21.1 percent is likely excessively large, even given the fact that India is such a large country that it would have difficulty obtaining massive imports if it had a major shortfall. A better guideline might be the stock-to-production ratio of Pakistan with stocks at 5.7 percent of production. $^{20}$

\section{ENHANCING MARKET EFFICIENCY THROUGH TRANSPARENCY AND PREDICTABILITY OF INTERVENTIONS}

There is a need for clear announcements of overall policy objectives and instruments to promote efficient private markets. This includes, first, clear annual announcements in advance of the (meher) planting season of target ceiling and floor prices for wheat, maize, and sorghum, and the potential interventions planned to achieve these targets. Second, clear announcements of quantities of planned public imports and exports are required so as not to discourage private trade (both imports and exports). Although, as noted above, when import parity prices are lower than the target ceiling price, private imports are more cost-effective, and they generally involve no costs to the government.

20 Note that in Bangladesh, India, and Pakistan, public stocks serve dual purposes: price stabilization and to provide grain for public food distribution programs. Since the early 1990 s, Bangladesh has used trade policy as well as market interventions and stocks to stabilize prices. 
TABLE 9.7 Cereal stock levels in selected Asian countries, average 2001-2007

\begin{tabular}{|c|c|c|c|c|c|c|c|}
\hline \multirow[b]{2}{*}{ Indicator } & \multirow{2}{*}{$\begin{array}{r}\text { Pakistan } \\
\text { Wheat }\end{array}$} & \multicolumn{3}{|c|}{ India } & \multicolumn{3}{|c|}{ Bangladesh } \\
\hline & & Wheat & Rice & Total & Rice & Wheat & Total \\
\hline Production (millions of metric tons) & 20.33 & 70.51 & 87.23 & 157.7 & 25.68 & 1.21 & 26.89 \\
\hline Stocks (millions of metric tons) & 1.16 & 17.06 & 16.4 & 33.5 & 0.54 & 0.23 & 0.77 \\
\hline Stocks/Production (\%) & 5.7 & 24.2 & 18.8 & 21.2 & 2.1 & 19.0 & 2.9 \\
\hline Per capita stocks (kilograms) & 7.6 & 16.2 & 15.4 & 31.6 & 1.7 & 3.8 & 5.5 \\
\hline
\end{tabular}

Source: Dorosh (2009).

\section{Conclusion}

Increases in cereal prices can have adverse effects on poor net food buyers. Conversely, falling domestic prices of some cereals (especially maize), typically at harvest time, can be detrimental to producers who are net sellers. Pricestabilization efforts are therefore an important consideration for Ethiopian policymakers. This chapter sheds light on options for cereal price stabilization in Ethiopia drawing on experiences of other developing countries. The international experience in food price stabilization shows that, while some countries have successfully stabilized prices at generally high fiscal cost, the efforts of many others have actually destabilized market prices at great fiscal cost. Ethiopia's interventions in wheat markets (there have been no major interventions in maize markets in Ethiopia in recent years) have met with limited success.

In this chapter we assess the extent of cereal price variation in Ethiopia. For the period 2009-2018, coefficients of variation (CV) of nominal wheat prices (which benefited from international trade) and maize (which did not) were both 0.280 . The coefficients of variation for real prices were only 0.132 for wheat and 0.214 for maize. While real maize price volatility is similar in Kenya $(C V=0.233)$, it is more variable in Uganda (CV $=0.291)$. The upshot is that a significant part of the variation in cereal prices in Ethiopia is explained by general inflation.

One of the major causes of price variability is also weather shocks, which lead to lower production. In this chapter we assess the extent to which Ethiopian stabilization efforts were effective during the major El Niñoinduced drought of 2015/2016. The consequent crop losses threatened the food security of an estimated 10 million people who were declared in need of emergency food assistance in addition to the 8 million already covered by the Productive Safety Net Program. Ultimately, a major food crisis was averted 
through a combination of a timely large-scale government and donor response along with substantial private market flows of cereals from surplus to deficit regions. Nonetheless, opportunities were missed to enhance food security and consumer welfare further by allowing private-sector imports of cereals to minimize the rise in cereal prices that occurred in 2016 and to reduce the fiscal costs to the government and donors.

In general, Ethiopia's policy options to further enhance cereal price stability vary by crop. Because Ethiopia imports wheat (either through food aid or through government commercial channels) in most years, liberalization of private-sector wheat imports can often provide a low-cost mechanism for providing a price ceiling at the import parity price. Enhancing price stability in other years through direct domestic market interventions, however, may be costly in fiscal terms and in terms of discouraging private-sector storage and trade. Given that Ethiopia's maize price is typically far below import parity (and far above export parity), private external trade in maize will generally not contribute to price stability. Moreover, interventions in domestic maize markets may be even more problematic for maize than for wheat because storage losses for maize are typically greater than those for wheat. Interventions to stabilize teff prices may be especially difficult, since very little teff is traded on the international market. Nonetheless, as urban markets for teff grow, private-sector commercial storage may increase over time and help stabilize market prices. 


\section{Appendix 9A: Historical Account of Major Food Shortages in Ethiopia}

TABLE 9A.1 Historical account of major food shortages in Ethiopia, 1971-2017

\begin{tabular}{|c|c|c|}
\hline Date & Region affected & Attributed causes and severity \\
\hline $1971-1975$ & Ethiopia & $\begin{array}{l}\text { Sequence of rain failures. Estimate 250,000 dead. } 50 \\
\text { percent livestock lost in Tigray and Wollo. }\end{array}$ \\
\hline $1978-1979$ & Southern Ethiopia & Failure of belg rains. \\
\hline 1982 & Northern Ethiopia & Late meher rains. \\
\hline $1983-1985$ & Ethiopia & $\begin{array}{l}\text { Sequence of rain failures. Eight million affected. Estimated } \\
\text { one million dead. Much livestock loss. }\end{array}$ \\
\hline 1987-1988 & Ethiopia & Drought of undocumented severity in peripheral regions. \\
\hline 1990-1992 & $\begin{array}{l}\text { Northern, eastern, and south- } \\
\text { western Ethiopia }\end{array}$ & $\begin{array}{l}\text { Rain failure and regional conflicts. Estimated four million } \\
\text { people suffering food shortage. }\end{array}$ \\
\hline $1993-1994$ & Tigray, Wollo, Addis Ababa & $\begin{array}{l}\text { Four million people requiring food assistance, including } \\
\text { demobilized army and Somali refugees. New droughts. }\end{array}$ \\
\hline $1997-2000$ & Eritrea, northern Tigray & Localized food shortages due to conflict. \\
\hline 2002-2003 & Ethiopia & Drought-induced crop shortages. \\
\hline 2009 & Southern Ethiopia & Localized drought. \\
\hline 2014-2015 & $\begin{array}{l}\text { Eastern Highlands, drought- } \\
\text { prone lowlands }\end{array}$ & $\begin{array}{l}\text { Localized droughts lead to belg harvest shortfalls; losses of } \\
\text { livestock. }\end{array}$ \\
\hline 2015-2017 & $\begin{array}{l}\text { Highlands, drought-prone } \\
\text { lowlands }\end{array}$ & $\begin{array}{l}\text { Localized drought reduces meher and belg harvests; } 10.2 \\
\text { million people in need of relief in mid- } 2016 .\end{array}$ \\
\hline
\end{tabular}

Source: 1971-1994: Webb and von Braun (1994: 21); Graham, Rashid, and Malek (2012), Table 9.1.

\section{Appendix 9B: Assessing Cereal Price Variability in Ethiopia}

World wheat prices in Ethiopia (measured in US dollars) from 2008 to 2018 were considerably more stable than the world maize prices with a coefficient of variation (CV) of 0.196 as compared to 0.287 for maize (column 1). Column 2 of Table 9B.1 shows that there was a relative difference in the coefficients of variation of nominal exchange rates across countries. Thus the coefficients of variation of border prices of maize measured in local currency units are rather similar for the three countries (column 3). In all three countries domestic maize prices (column 4) were on average slightly above border prices; wheat prices in Ethiopia were on average 46.9 percent above border prices, though, as discussed in the chapter regarding price effects of alternative policies, there were considerable periods in which domestic wheat prices were somewhat below border prices. Domestic prices measured in US dollars (column 5) were 
TABLE 9B.1 Average prices for wheat and maize in Ethiopia and maize in Kenya and Uganda, 2009-2018

\begin{tabular}{|c|c|c|c|c|c|c|c|}
\hline & $\begin{array}{l}\text { World } \\
\text { price }\end{array}$ & $\begin{array}{l}\text { Exchange } \\
\text { rate }\end{array}$ & $\begin{array}{l}\text { Border } \\
\text { price }\end{array}$ & $\begin{array}{l}\text { Domestic } \\
\text { price }\end{array}$ & $\begin{array}{l}\text { Domestic } \\
\text { price }\end{array}$ & $\begin{array}{c}\text { Border } \\
\text { price/CPI }\end{array}$ & $\begin{array}{l}\text { Domestic } \\
\text { price/CPI }\end{array}$ \\
\hline & $\begin{array}{l}\text { US\$ per } \\
\text { metric ton } \\
\text { (1) }\end{array}$ & $\begin{array}{l}\text { Icu } \\
/ \$ \\
(2)\end{array}$ & $\begin{array}{l}\text { Icu per } \\
\text { kilogram } \\
\text { (3) }\end{array}$ & $\begin{array}{l}\text { Icu per } \\
\text { kilogram } \\
\text { (4) }\end{array}$ & $\begin{array}{c}\$ \text { per } \\
\text { metric ton } \\
\text { (5) }\end{array}$ & $\begin{array}{l}\text { Icu (2018) } \\
\text { per } \\
\text { kilogram } \\
(6)\end{array}$ & $\begin{array}{l}\text { Icu (2018) } \\
\text { per } \\
\text { kilogram } \\
\text { (7) }\end{array}$ \\
\hline \multicolumn{8}{|l|}{ Ethiopia wheat } \\
\hline Mean & 262.12 & 19.12 & 5.53 & 8.07 & 418.74 & 8.41 & 11.86 \\
\hline Standard deviation & 51.42 & 4.16 & 1.31 & 2.26 & 51.42 & 2.29 & 1.56 \\
\hline CV & 0.196 & 0.217 & 0.237 & 0.280 & 0.123 & 0.272 & 0.132 \\
\hline \multicolumn{8}{|l|}{ Ethiopia maize } \\
\hline Mean & 204.02 & 19.12 & 4.32 & 4.86 & 254.38 & 2.57 & 2.60 \\
\hline Standard deviation & 58.54 & 4.16 & 1.12 & 1.36 & 40.65 & 0.84 & 0.56 \\
\hline CV & 0.287 & 0.217 & 0.260 & 0.280 & 0.160 & 0.328 & 0.214 \\
\hline \multicolumn{8}{|l|}{ Kenya maize } \\
\hline Mean & 204.02 & 90.81 & 21.05 & 31.42 & 348.28 & 27.92 & 40.73 \\
\hline Standard deviation & 58.54 & 9.49 & 4.74 & 7.78 & 67.33 & 8.61 & 9.50 \\
\hline CV & 0.287 & 0.104 & 0.225 & 0.248 & 0.193 & 0.211 & 0.233 \\
\hline \multicolumn{8}{|l|}{ Uganda maize } \\
\hline Mean & 204.02 & 2841.45 & 651.14 & 720.64 & 255.08 & 818.58 & 876.81 \\
\hline Standard deviation & 58.54 & 590.90 & 148.22 & 250.65 & 75.04 & 191.42 & 255.13 \\
\hline CV & 0.287 & 0.208 & 0.228 & 0.348 & 0.294 & 0.234 & 0.291 \\
\hline
\end{tabular}

Source: Authors' calculations from Dorosh, Minten, and Stifel (2015); EGTE (2018); IMF (2018); and Ethiopia, CSA (2018) data.

Note: $\mathrm{CPI}=$ Consumer Price Index; Icu = local currency unit; $\mathrm{CV}=$ coefficent of variation.

considerably more stable than domestic prices measured in local currency. Finally, real prices of both wheat and maize in Ethiopia in local currency units (calculated using the domestic CPIs as deflators) were much more stable than the nominal domestic prices of these commodities.

Over this same period (2009-2018), Ethiopia's overall domestic inflation (measured by the CPI), as well as the growth rate of domestic maize prices, were higher than those in Kenya and Uganda. ${ }^{21}$ The average increase in the CPI in Ethiopia was 0.98 percent per month, compared to only 0.60 percent per month in Kenya and 0.53 percent per month in Uganda. Likewise, the average growth rates in maize prices in Ethiopia was considerably higher

21 For more details on the exchange rates and cereal prices across these three countries, see Dorosh et al. (2018). 
than those in Kenya or Uganda (0.66 percent, 0.35 percent, and 0.49 percent, respectively). Over this period, Ethiopia's nominal exchange rate (relative to the US dollar) increased by 0.64 percent per month. This was considerably less than the average monthly growth rate in the CPI, so the ratio of the exchange rate to the CPI (a crude measure of the real exchange rate that does not take into consideration changes in world prices), appreciated by 0.20 percent per month, almost identical to the change in this measure for Kenya ( 0.19 percent per month). This appreciation of the real exchange rate encouraged imports and reduced export competitiveness. In contrast, Uganda's real exchange rate depreciated over this period.

\section{References}

AKLDP (Agriculture Knowledge, Learning, Documentation and Policy Project). 2016. Food Security in Ethiopia in 2016: Analysing Crop Production and Market Function after the Main Meher Agricultural Season. Addis Ababa: AKLDP, USAID (United States Agency for International Development).

Arguez, A., I. Durre, S. Applequist, M. Squires, R. Vose, X. Yin, and R. Bilotta. 2010. “NOAA's U.S. Climate Normals (1981-2010)." NOAA National Centers for Environmental Information. Accessed July 5, 2017. www.ncdc.noaa.gov/data-access/land-based-station-data/ land-based-datasets/climate-normals/1981-2010-normals-data.

Bachewe, F., G. Berhane, B. Minten, and A. S. Taffesse. 2018. "Agricultural Transformation in Africa? Assessing the Evidence in Ethiopia." World Development 105: 286-298.

Bachewe, F., F. Yimer, and B. Minten. 2017. Agricultural Price Evolution in Drought versus Non-Drought Affected Areas in Ethiopia: An Updated Assessment Using National Producer Data (January 2014 to January 2017). IFPRI-ESSP Working Paper 106. Addis Ababa: IFPRI/ESSP (International Food Policy Research Institute/Ethiopia Strategy Support Program).

Bellemare, M. F., C. B. Barrett, and D. R. Just. 2013. "The Welfare Impacts of Commodity Price Volatility: Evidence from Rural Ethiopia." American Journal of Agricultural Economics 95 (4): 877-899.

Berhane, G., D. O. Gilligan, J. Hoddinott, N. Kumar, and A. S. Taffesse. 2014. "Can Social Protection Work in Africa? The Impact of Ethiopia's Productive Safety Net Programme." Economic Development and Cultural Change 63 (1): 1-26.

Berhane, G., L. McBride, K. Tafere, and S. Tamiru. 2013. "Patterns in Foodgrain Consumption and Calorie Intake." In Food and Agriculture in Ethiopia: Progress and Policy Challenges, edited by P. Dorosh and S. Rashid, 190-216. Philadelphia: University of Pennsylvania Press. 
Chapoto, A., and T. Jayne. 2009. Effects of Maize Marketing and Trade Policy on Price

Unpredictability in Zambia. Food Security Research Project Working Paper 38. East Lansing, US: Michigan State University.

Coady, D., P. Dorosh, and B. Minten. 2009. "Evaluating Alternative Policy Responses to Higher

World Food Prices: The Case of Increasing Rice Prices in Madagascar." American Journal of Agricultural Economics 91 (3): 711-722.

Coll-Black, S., D. Gilligan, J. Hoddinot, N. Kumar, A. Taffesse, and W. Wiseman. 2013.

"Targeting Food Security Interventions in Ethiopia: The Productive Safety Net Programme." In Food and Agriculture in Ethiopia: Progress and Policy Challenges, edited by P. Dorosh and S. Rashid, 280-317. Philadelphia: University of Pennsylvania Press.

Diao, X., and A. Kennedy. 2016. "Economywide Impact of Maize Export Bans on Agricultural Growth and Household Welfare in Tanzania: A Dynamic Computable General Equilibrium Model Analysis." Development Policy Review 34 (1): 101-134.

Dorosh, P. A. 2001. "Trade Liberalization and National Food Security: Rice Trade between Bangladesh and India." World Development 29 (4): 673-689.

_. 2008. "Food Price Stabilization and Food Security: The International Experience." Bulletin of Indonesian Economic Studies 44 (1): 93-114.

_.2009. "Price Stabilization, International Trade and National Cereal Stocks: World Price Shocks and Policy Response in South Asia." Food Security 1 (2): 137-149.

Dorosh, P., and H. Ahmed. 2009. Foreign Exchange Rationing, Wheat Markets and Food Security in Ethiopia. IFPRI-ESSP Working Paper 4. Addis Ababa: IFPRI/ESSP.

- 2011. "Foreign Exchange Rationing and Wheat Markets in Ethiopia." Ethiopian Journal of Economics 20 (2): 83-104.

Dorosh, P., B. Minten, and D. Stifel. 2015. "Cereal Price Stabilization in Ethiopia: Implications from International Experience." In Cereals Price Policy and Analysis for Ethiopia in the Context of Rapid Production Growth, edited by D. Chanyalew, J. W. Mellor, B. Minten, and T. Kuma. Unpublished 2014 conference proceedings, ESSP/IFPRI, Addis Ababa.

Dorosh, P., and S. Rashid. 2013. "Trade Subsidies, Export Bans and Price Stabilization: Lessons of Bangladesh-India Rice Trade in the 2000s.” Food Policy 41: 103-111.

Dorosh, P., J. Smart, B. Minten, and D. Stifel. 2018. Droughts, Cereal Prices, and Price Stabilization Options in Ethiopia. IFPRI-ESSP Working Paper 126. Addis Ababa: IFPRI/ ESSP.

EGTE (Ethiopian Grain Trade Enterprise). 2018. Commodity Statistics. Accessed July 5, 2019. www.egte-ethiopia.com/en. 
Ethiopia, CSA (Central Statistical Agency). 2016. Annual Agricultural Sample Survey Data Bulletins. Accessed July 5, 2017. www.csa.gov.et/survey-report/category/58-meher-main -season-agricultural-sample-survey.

-2018. Unpublished market price data.

Ethiopia, EPAU (Ethiopian Policy Analysis Unit). 2018. Unpublished data.

Ethiopia, ERCA (Ethiopian Revenues and Customs Authority). Unpublished imports data.

FAO (Food and Agriculture Organization of the United Nations). 2016a. 2015-2016 El Niño: Early Action and Response for Agriculture, Food Security and Nutrition Report. Update \#6. Accessed July 5, 2019. http://reliefweb.int/sites/reliefweb.int/files/resources/a-i5855e.pdf.

—.2016b. Ethiopia Situation Report-November 2016. Accessed July 5, 2019. www.fao.org/ emergencies/resources/documents/resources-detail/en/c/456019/.

—. 2017a. Ethiopia Situation Report-January 2017. Accessed July 5, 2019. www.fao.org/ emergencies/resources/documents/resources-detail/en/c/463347/.

—.2017b. Ethiopia Situation Report-May 2017. Accessed July 5, 2019. www.fao.org/ emergencies/resources/documents/resources-detail/en/c/886170/.

—.2017c. Food Aid Shipments (WFP). Accessed July 5, 2019. www.fao.org/faostat/en/ \#data/FA.

2017d. Production Indices. Accessed July 5, 2019. www.fao.org/faostat/en/\#data/QI.

FAO and WFP (World Food Programme). 2007. Special Report: FAO/WFP Crop and Food Supply Assessment Mission to Ethiopia. Accessed August 30, 2019. www.fao.org/3/a-j9325e.pdf.

- 2019a. Special Report: FAO/WFP Crop and Food Security Assessment Mission to South Sudan. Accessed August 30, 2019. www.fao.org/3/ca3643en/ca3643en.pdf.

— 2019b. FAO/WFP Joint Rapid Food Security Assessment-Democratic People's Republic of Korea. Accessed August 30, 2019. www.fao.org/3/ca4447en/ca4447en.pdf.

Ferrand, A. 2018. Exchange Rate Management and Export Growth: Lessons for Ethiopia. K4D Helpdesk Report. Brighton, UK: Institute of Development Studies.

FEWS NET. 2014. "Ethiopia Food Security Outlook Update: Food Security Likely to Deteriorate in Afar and Southern Somali." Accessed July 5, 2017. www.fews.net/east-africa/ethiopia/ food-security-outlook-update/june-2014.

- 2015. "Ethiopia Food Security Outlook Update: Belg Production Likely to Be Far Below Average in June/July." Accessed July 5, 2017. www.fews.net/east-africa/ethiopia/ food-security-outlook-update/may-2015.

2017. "Ethiopia Food Security Outlook: Meher Harvests to Improve Food Security in October, but Deyr Rains May Be Below Average.” Accessed July 5, 2017. www.fews.net/sites/ default/files/documents/reports/Ethiopia_OL_2016_06_final.pdf. 
Gondwe, A., and B. Baulch. 2017. The Case for Structured Markets in Malawi. IFPRI-ESSP Policy Note 29. Addis Ababa: IFPRI/ESSP.

Graham, J., S. Rashid, and M. Malek. 2012. "Disaster Response and Emergency Risk Management in Ethiopia." In Food and Agriculture in Ethiopia: Progress and Policy Challenges, edited by P. Dorosh and S. Rashid, 256-279. Philadelphia: University of Pennsylvania Press.

Hill, R., and H. Fuje. 2017. "What Is the Impact of Drought on Prices? Evidence from Ethiopia.” Unpublished, Poverty and Equity Global Practice, Africa Region, World Bank, Washington, DC.

Hirvonen, K., T. P. Sohnesen, and T. Bundervoet. 2018. Impact of Ethiopia's 2015 Drought on Child Undernutrition. IFPRI-ESSP Working Paper 114. Addis Ababa: IFPRI/ESSP.

IFPRI (International Food Policy Research Institute). 2017. "Ethiopia Productive Safety Net Program (PSNP) Baseline Community Survey, 2013.” Harvard Dataverse, V1. Accessed July 5, 2018. https://doi.org/10.7910/DVN/SNL11W.

IMF (International Monetary Fund). 2018. International Financial Statistics. Accessed July 5 , 2018. http://data.imf.org/regular.aspx?key=61545850.

Jayne, T., R. Myers, and J. Nyoro. 2008. “The Effects of NCPB Marketing Policies on Maize Market Prices in Kenya." Agricultural Economics 38: 313-325.

Jayne, T., and D. Tschirley. 2009. "Food Price Spikes and Strategic Interactions between the Public and Private Sectors: Market Failures or Governance Failures?" Paper presented at the FAO meeting on Institutions and Policies to Manage Global Market Risks and Price Spikes in Basic Food Commodities, Rome, October 26-27.

Knippenberg, E., and J. Hoddinott. 2017. Shocks, Social Protection, and Resilience: Evidence from Ethiopia. IFPRI-ESSP Working Paper 109. Addis Ababa: IFPRI/ESSP.

Leta, S., and F. Mesele. 2014. "Spatial Analysis of Cattle and Shoat Population in Ethiopia: Growth Trend, Distribution and Market Access." SpringerPlus 3 (310). https://link.springer.com/ article/10.1186/2193-1801-3-310\#citeas.

Mann, M. L., J. M. Warner, and A. S. Malik. 2018. Predicting High-Magnitude Low-Frequency Crop Losses Using Machine Learning: An Application to Cereal Crops in Ethiopia. IFPRI-ESSP Working Paper 120. Addis Ababa: IFPRI/ESSP.

Minten, B., M. Dereje, E. Engida, and T. Kuma. 2019. "Coffee Value Chains on the Move: Evidence in Ethiopia." Food Policy 83 (February): 370-383.

Minten, B., and P. Dorosh. 2006. Rice Markets in Madagascar in Disarray: Policy Optionsfor Increased Efficiency and Price Stabilization. World Bank Africa Region Working Paper 101. Washington, DC: World Bank. 
Minten, B., D. Stifel, and S. Tamru. 2014. "Structural Transformation of Cereal Markets in Ethiopia." Journal of Development Studies 50 (5): 611-629.

Rashid, S., P. Dorosh, and D. Alemu. 2018. "Grain Markets, Disaster Management, and Public Stocks: Lessons from Ethiopia." Global Food Security 19: 31-39.

Rashid, S., and S. Lemma. 2014. Public Wheat Imports into Ethiopia since 2008: The Rationales and Cost-Effectiveness. REAP (Research for Ethiopia's Agriculture Policy)/IFPRI Discussion Paper. Washington, DC: IFPRI.

Rashid, S., and A. Negassa. 2012. "Policies and Performance of Ethiopia Cereal Markets." In Food and Agriculture in Ethiopia: Progress and Policy Challenges, edited by P. Dorosh and S. Rashid, 53-83. Philadelphia: University of Pennsylvania Press.

Tafere, K., P. Zelekawork, A. S. Taffesse, T. Nigussie, and T. Seneshaw. 2009. Food Demand Elasticities in Ethiopia: Estimates Using 2004/05 Household Income Consumption Expenditure (HICE) Survey Data. Ethiopia Strategy Support Program II, Discussion Paper 11. Addis Ababa: IFPRI.

Taffesse, A. S., P. A. Dorosh, and S. Asrat. 2013. "Crop Production in Ethiopia: Regional Patterns and Trends." In Food and Agriculture in Ethiopia: Progress and Policy Challenges, edited by P. Dorosh and S. Rashid, 53-83. Philadelphia: University of Pennsylvania Press.

Tamru, S., B. Minten, and J. Swinnen. 2019. Trade, Value Chains, and Rent Distribution with Foreign Exchange Controls: Coffee Exports in Ethiopia. Ethiopia Strategy Support Program Working Paper 136 (September). Addis Ababa: IFPRI/ESSP.

TesfaNews. 2016. “Food Aid Destined for Ethiopia’s Hungry Stuck in Djibouti Port.” March 24. Accessed July 5, 2017. www.tesfanews.net/ethiopia-food-aid-stuck-djibouti-port/.

USAID (United States Agency for International Development). 2016. Ethiopia-Complex Emergency Fact Sheet \#8, Fiscal Year (FY) 2016. Accessed July 5, 2017. https://scms.usaid.gov/ sites/default/files/documents/1866/ethiopia_ce_fs08_04-13-2016.pdf.

USDA-FAS (United States Department of Agriculture-Foreign Agricultural Service). 2012.

"Ethiopia Grain and Feed Annual Report." Global Agricultural Information Network Report ET 1201. Accessed August 30, 2019. https://gain.fas.usda.gov/Recent\%20GAIN\%20 Publications/Grain\%20and\%20Feed\%20Annual_Addis\%20Ababa_Ethiopia_4-17-2012 .pdf.

Webb, P., and J. von Braun. 1994. Famine and Food Security in Ethiopia: Lessons for Africa. Washington, DC: IFPRI.

WFP (World Food Programme). 2014a. "WFP Ethiopia July Monthly Situation Report \#6." Accessed July 5, 2017. http://reliefweb.int/sites/reliefweb.int/files/resources/WFP\%20 Ethiopia\%20Monthly\%20Report\%20of\%20July\%202014.pdf. 
.2014b. “WFP Ethiopia October Monthly Situation Report \#7.” Accessed July 5, 2017. http://reliefweb.int/report/ethiopia/wfp-ethiopia-october-monthly-situation-report-7.

_ 2015a. “WFP Ethiopia May Monthly Situation Report \#1.” Accessed July 5, 2017. https:// reliefweb.int/report/ethiopia/wfp-ethiopia-may-monthly-situation-report-1.

.2015b. “WFP El Niño: Preparedness and Response, Situation Report \#1, 06 November 2015.” Accessed July 5, 2017. http://reliefweb.int/report/ethiopia/wfp-ethiopia-may -monthly-situation-report-1.

_. 2016a. "WFP Ethiopia Drought Emergency Household Food Security Bulletin \#1." Accessed July 5, 2017. http://reliefweb.int/report/ethiopia/wfp-ethiopia-drought-emergency -household-food-security-bulletin-1.

— 2016b. "WFP Ethiopia Drought Emergency Situation Report \#1.” Accessed July 5, 2017. www.humanitarianresponse.info/en/operations/ethiopia/document/wfp-ethiopia-drought -emergency-situation-report-1-13-april-2016.

.2016c. “WFP Ethiopia Drought Emergency Situation Report \#2.” Accessed July 5, 2017. http://reliefweb.int/report/ethiopia/wfp-ethiopia-drought-emergency-situation-report -2-3-may-2016.

—. 2016d. "WFP Ethiopia Drought Emergency Situation Report \#3.” Accessed July 5, 2017. http://reliefweb.int/report/ethiopia/wfp-ethiopia-drought-emergency-situation-report -3-20-may-2016.

—. 2016e. "WFP El Niño 2015-2016: Preparedness and Response, Situation Report \#4.” Accessed July 5, 2017. http://reliefweb.int/report/world/wfp-el-ni-o-2015-2016-preparedness -and-response-situation-report-4-24-may-2016.

_. 2016f. "WFP Ethiopia Drought Emergency Household Food Security Monitoring Bulletin \#3.” Accessed July 5, 2017. https://reliefweb.int/report/ethiopia/wfp-ethiopia -drought-emergency-household-food-security-bulletin-3.

—. 2016g. "WFP Ethiopia Situation Report \#8.” Accessed July 5, 2017. http://reliefweb.int/ report/ethiopia/wfp-ethiopia-drought-emergency-situation-report-8-4-august-2016

—.2016h. “WFP Ethiopia Situation Report \#9.” Accessed July 5, 2017. http://reliefweb.int/ report/ethiopia/wfp-ethiopia-drought-emergency-situation-report-9-15-august-2016

—. 2016i. "WFP Ethiopia Situation Report \#14.” Accessed July 5, 2017. http://reliefweb.int/ report/ethiopia/wfp-ethiopia-drought-emergency-situation-report-14-1-30-november-2016.

. 2017a. "WFP East and Central Africa Horn of Africa Drought Crisis Situation Report \#02.” Accessed July 5, 2017. https://reliefweb.int/report/somalia/wfp-east-central-africa-horn -africa-drought-crisis-situation-report-2-20-february. 
— 2017b. “WFP Ethiopia 2017 Emergency Situation Report \#1.” Accessed July 5, 2017. http://reliefweb.int/report/somalia/wfp-east-central-africa-horn-africa-drought-crisis -situation-report-2-20-february.

—. 2017c. “WFP Ethiopia 2017 Emergency Situation Report \#3.” Accessed July 5, 2017. http://reliefweb.int/report/ethiopia/wfp-ethiopia-drought-emergency-situation-report -3-may-2017.

WFP and Ethiopia, CSA (Ethiopia, Central Statistical Agency). 2019. "Comprehensive Food Security and Vulnerability Analysis (CFSVA).” Accessed August 30, 2019. https://reliefweb .int/sites/reliefweb.int/files/resources/wfp_ethiopia_cfsva_report_june_2019.pdf.

Wiseman, W., J. Van Domelen, and S. Coll-Black. 2010. Designing and Implementing a Rural Safety Net in a Low Income Setting: Lessons Learned from Ethiopia's Productive Safety Net Program 2005-2009. Washington, DC: World Bank.

World Bank. 2016. Devaluing the Exchange Rate in Ethiopia: Why, When and How. June. Addis Ababa. 
